\title{
Attribute of trace fossils of Laisong flysch sediments, Manipur, India
}

\author{
Kumar S Khaidem ${ }^{1}$, Hemanta S Rajkumar ${ }^{2, *}$ and Ibotombi Soibam ${ }^{3}$ \\ ${ }^{1}$ Department of Geology, DM College of Science, Imphal 795 001, India. \\ ${ }^{2}$ Department of Geology, United College Lambung, Chandel 795 127, India. \\ ${ }^{3}$ Department of Earth Sciences, Manipur University, Canchipur 795 003, India. \\ *Corresponding author.e-mail: mohnarooprajkumar@gmail.com
}

The depositional basin in which the Late Eocene-Early Oligocene Laisong flysch sediments Barail Group, Manipur region (Indo-Myanmar ranges) have been deposited is generally considered to be of deep marine environment. However, field observation indicates the presence of many shallow environment signature characteristics of marginal to sublittoral marine settings, in addition to the general occurrence of deep marine turbidites. To address this aspect, ichnological analyses of the Laisong Formation has been attempted for elucidating palaeoenvironmental setting prevalent during the deposition of these sediments. Presence of 36 ichnospecies belonging to 33 ichnogenera has so far been identified. The ichnospecies may be grouped into different ichnofacies such as Skolithos-Cruziana mixed ichnofacies, Cruziana ichnofacies, Skolithos ichnofacies, Zoophycos ichnofacies, Nereites ichnofacies and Teredolites ichnofacies which decrease in abundance in this order of sequence with Skolithos-Cruziana mixed ichnofacies being the most dominant. The above-mentioned ichnofacies are found associated with sedimentary structures such as large sole marks, parallel laminations, massive and structureless beds, rip-up clasts, etc., which are characteristics of submarine fan deposits below the storm wave base and current ripples, herringbone structures, hummocky cross stratifications, pot casts, rain prints, etc., that marked shallow marginal marine setting such as tidal flats, deltas and shoreface. With such observations it is very likely that the Laisong sediments were formed in a tectonically active basin with varied bathymetric ranges indicating alternate transgressive and regressive nature.

\section{Introduction}

The Palaeogene rocks of Manipur in the IndoMyanmar Ranges comprise of the flysch and molásse sediments. The flysch sediments are represented by the Disang Group (Upper Cretaceous-Late Eocene) and the Barail Group (Late Eocene-Late Oligocene) whereas the molásse sediments are represented by the Surma Group (Late OligoceneMiocene). Both the flysch and molásse sediments are characterized by moderately rich occurrence of trace fossils. It is a well established fact that trace fossils can be used in the interpretation of paleoenvironment of depositional basin (McIlroy 2004; Miller 2007; Rodriguez-Tovar 2010). In the Indian context, a number of ichnological studies have been carried out recently on various stratigraphic horizons ranging in age from Cambrian to Miocene primarily from peninsular India, to understand their depositional environments (Patel et al. 2008, 2009, 2014; Malarkodi et al. 2009; Nagendra et al. 2010; Saha et al. 2010; Joseph et al. 2012; Srivastava and Mankar 2012; Chakraborty et al. 2013; Desai and Saklani 2014; Kulkarni and Borkar 2014; Pandey et al. 2014; Patel 2014). But ichnological research of the Palaeogene succession of

Keywords. Trace fossils; Laisong flysch; Late Eocene; Early Oligocene; paleoenvironment; Manipur; India. 
Indo-Myanmar ranges is very scanty. Tripathi and Satsangi (1982) for the first time reported trace fossil Ophiomorpha isp. from the Palaeogene sediments of northeast India (Manipur). Rajkumar (2005) studied three ichnospecies, namely Chondrites isp., Ophiomorpha isp. and Thalassinoides isp. from the Disang-Barail transition, Manipur and indicated a neritic depositional zone. Later ichnological analysis of the above transitional sediments has been carried out on the basis of eight ichnospecies and designated a shallow marine environment with occasional high energy conditions (Rajkumar et al. 2008). Rajkumar and Klein (2014) suggested a marginal marine setting for certain horizons in the basal part of Laisong (Disang-Barail transition) based on the preservation of perissodactyl tracks and associated invertebrate trace fossils. The abovecited ichnological research of the Disang-Barail transition differs from the present research paper described herein, in that, the present paper deals with trace fossils from the Laisong Formation which is practically just above the Disang-Barail transition. Mairenbam and Kushwaha (2008) have also reported trace fossils from the Eocene-Oligocene deposits between Bijang and Tupul, Manipur. Mairenbam et al. (2010) presented the palaeoenvironmental importance of Bhuban and Boka Bil formations, Surma Group of Manipur and proposed a frequent fluctuating sea level, moderate to strong energy condition, subtidal to lower intertidal environment, rich in organic nutrients. In comparison to Manipur, ichnological studies of Neogene rocks have been more frequently undertaken in the adjoining state of Mizoram due to the availability of better exposures and relatively greater abundance of trace fossils. Tiwari et al. (2011) studied the palaeoenvironmental significance of Bhuban sediments of Mizoram and indicated a shifting substrate and high energy conditions in foreshore zone and unconsolidated, poorly sorted soft substrate and low energy condition in the shoreface-offshore zone, respectively. Rajkumar et al. (2012) suggested a shallow marine depositional basin characterised by moderately high energy and well oxygenated conditions with a corresponding bathymetric position in the intertidal to subtidal zone for the middle Bhuban, Surma Group of Mizoram. Tiwari et al. (2013) reported Funalichnus bhubani isp. nov. from Bhuban Formation, Surma Group (LowerMiddle Miocene) of Aizawl, Mizoram and inferred a shoreface and sheltered foreshore environment. Rajkonwar et al. (2013, 2014a, b) also worked on the relationship between ichnofauna and palaeodepositional environments of Bhuban Formation, Mizoram.

Besides, palaeoenvironmental aspects of the Palaeogene sediments of Manipur and adjoining states have also been studied by various researchers through a non-ichnological approach. Guleria et al. (2005) studied the Palaeogene plant materials of Upper Disang and Lower Barail sediments of Manipur and indicated the existence of a moist tropical environment at the time of deposition; Dasgupta and Biswas (2000) indicated a shallow water inner neritic zone for the Disang sediments during Late Eocene and shallow brackish water condition for the Barail sediments during Oligocene on the basis of microfaunal assemblages; Biswas and Mukhopadhyay (2011) described the Palaeogene submarine fan from the Jenam Formation, Barail Group of Jenamghat, Assam as to have been formed in deep-water proximal- to mid-fan depositional setting based on lithofacies analysis. Yengkhom et al. (2013) studied pollen and spores and suggested a warm, shallow marine environment similar to modern tidal flats for the Uppermost Disang sediments transitional to basal part of Laisong Formation.

The present paper attempts to analyse the palaeoenvironmental aspects of the basin in which the Laisong sediments were deposited using the moderately diverse trace fossils and the associated sedimentary features. This will certainly help us to fill up the gap in our knowledge with respect to the trace fossil assemblages of Laisong succession and their palaeoenvironmental significance. The 33 ichnogenera and 36 ichnospecies, so far studied and identified in the present work are named according to the rules of International Code of Zoological Nomenclature and described alphabetically. The ichnospecies are archived in the Mantrimayum Ichnological Museum (MIM) of United College Lambung Chandel, Manipur. Figure 1 represents the geological map of Manipur showing the different study sites.

\section{Geological setting and location}

The Barail Group of sediments belong to the Central Naga Hill Palaeogene flysch sediments (Acharyya et al. 1986). The principal Palaeogene and Neogene lithounits of Manipur comprise of flysch sediments of the Disang and Barail Groups and molásse sediments of the Surma and Tipam Groups, respectively (table 1). The Disang Group consists of a monotonous sequence of dark grey to black splintery shales, and occasional rhythmites of shales and siltstones/fine-grained sandstones, especially in the upper horizon, forming the principal lithounits of the eastern half of the state of Manipur. The Barail Group, mainly of Oligocene age with some possible extension towards the Upper Eocene, consists of $\sim 3000-\mathrm{m}$ thick arenaceous beds intercalated with shales, carbonaceous shale, silty shales and siltstones which rest over the 


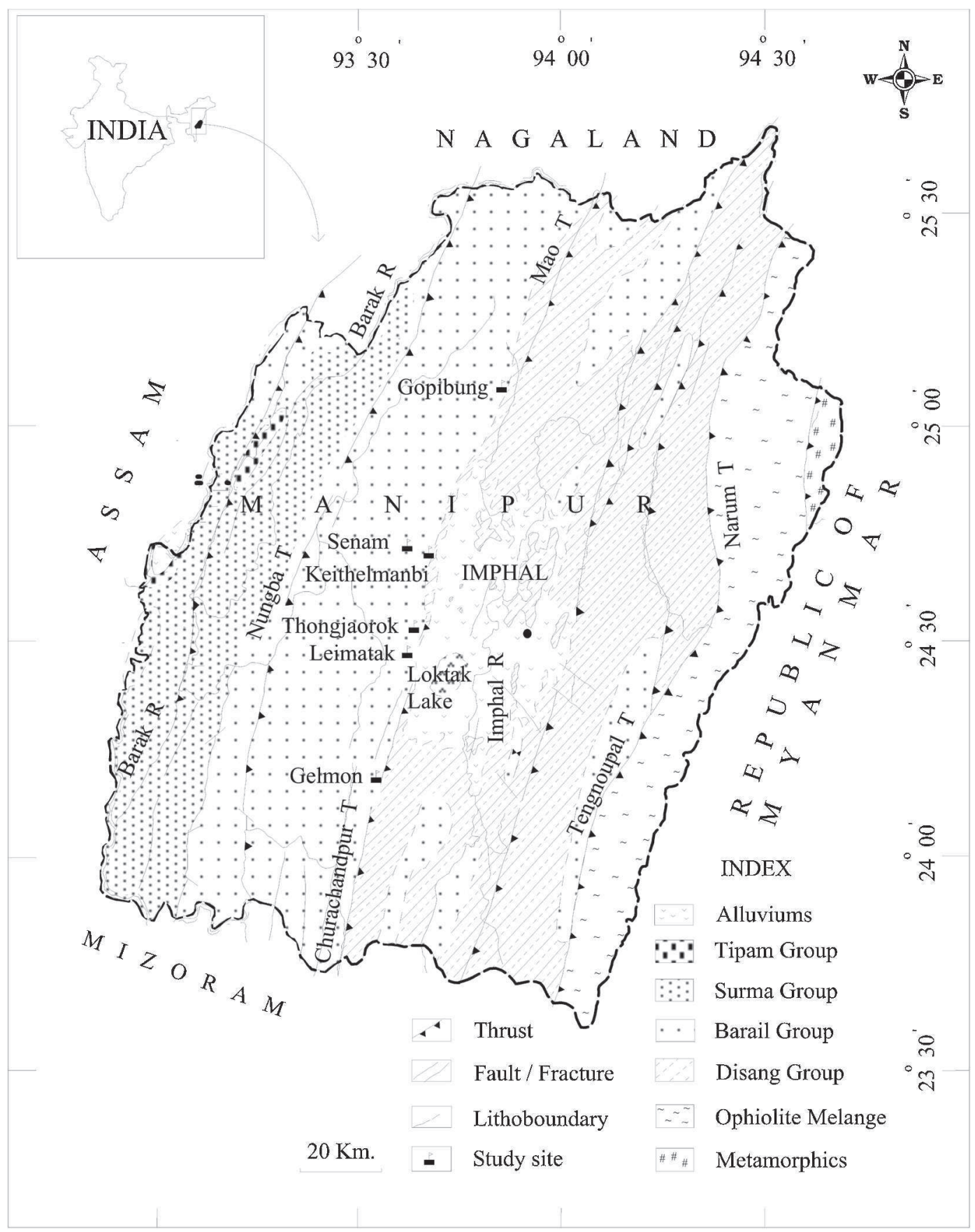

Figure 1. Geological map of Manipur indicating studied locations.

Disang Group. The basal part of the Barail Group has a gradational (as well as tectonic) contact with the Disang Group (Soibam 1998), which is related with a gradual change from a dominantly argillaceous deep marine (cf. Mathur and Evans 1964) to a mainly arenaceous shallow marine depositional environment (Rao 1983; Rajkumar et al. 2008; Yengkhom et al. 2010). The Barail Group has been divided into three formations namely the Laisong, Jenam and Renji (Evans 1932). The Laisong Formation, approximately 1200-m thick, is characterized by intercalations of shales, silty shales, siltstones and fine-to-medium grained sandstones. These sediments are characterized by two groups of sedimentary structures. One kind represents shallow marine environment such as straight crested ripples, linguidal ripple, cross beddings, cross laminations, gutter casts, pot casts, herringbone structures, hummocky cross stratifications, imbricate structures, rain prints, etc., indicating wave and current influence and deposition above the storm wave base. The second group of sedimentary structures are characteristics of turbidites. Examples are massive and structureless beds, parallel 
Table 1. Generalized stratigraphic succession of Manipur (modified from Soibam 1998; Rajkumar and Klein 2014).

\begin{tabular}{|c|c|c|c|}
\hline Group & Formation & Age & Lithological and palaeontological features \\
\hline \multirow[t]{5}{*}{ Alluviums } & Younger & Recent & $\begin{array}{l}\text { Dark grey to black clay, silt and sandy deposits of fluvio-lacustrine } \\
\text { origin of the Imphal Valley. Fluvial alluviums in the Barak Valley } \\
\text { area of western plains. }\end{array}$ \\
\hline & Older & Pleistocene & $\begin{array}{l}\text { Clay, sand, gravel, pebbles, boulder deposits of the foothills and old } \\
\text { river terraces. Skeleton remains of horse about } 40 \mathrm{Ka} \text { old reported } \\
\text { from Kangla. }\end{array}$ \\
\hline & $---_{-}^{-}-$ & - - - - - - - - - & Unconformity - - - - - - - - - - - - - - - - - - - - - - - - - - - - - - \\
\hline & $\begin{array}{l}\text { Girujan } \\
\text { Clays }\end{array}$ & Late Miocene & (Likely exposure in the foothills of Jiribam) \\
\hline & $\begin{array}{l}\text { Tipam } \\
\text { sandstone }\end{array}$ & & $\begin{array}{l}\text { Greenish to blue, moderate to coarse ferruginous sandstone with } \\
\text { sandy shale, clay. Often brown to orange due to weathering. } \\
\text { Molásse type of deposits (total lack of palaeontological report). }\end{array}$ \\
\hline \multirow[t]{3}{*}{ Surma } & $\begin{array}{l}\text { Boka Bil } \\
(\sim 1400 \mathrm{~m}) \\
\text { Bhuban }\end{array}$ & Late Miocene & $\begin{array}{l}\text { Shale, sandy shale, siltstone, ferruginous sandstone, massive to } \\
\text { false-bedded ferruginous sandstone. Mainly Cruziana ichnofacies. }\end{array}$ \\
\hline & $(\sim 1400 \mathrm{~m})$ & $\begin{array}{l}\text { Late Oligocene } \\
\text { Early Miocene }\end{array}$ & $\begin{array}{l}\text { Alternations of sandstone and shale with more argillaceous horizons } \\
\text { in the middle and minor conglomerates. Mainly Cruziana } \\
\text { ichnofacies. Transitional characters from flysch to molásse } \\
\text { sediments. }\end{array}$ \\
\hline & $-1-\cdots$ & $-\cdots-----1$ & Unconformity - - - - - - - - - - - - - - - - - - - - - - - - - - - - - \\
\hline \multirow[t]{2}{*}{ Barail } & $\begin{array}{l}\text { Renji } \\
(\sim 800 \mathrm{~m}) \\
\text { Jenam } \\
(\sim 1200 \mathrm{~m})\end{array}$ & Late Oligocene & $\begin{array}{l}\text { Massive to thickly bedded sandstones. Ichnotaxa are similar with } \\
\text { those of Jenam. Mainly Cruziana ichnofacies. Flysch sediments. } \\
\text { Massive to thickly bedded sandstones with carbonaceous shale } \\
\text { horizons. Ichnotaxa are similar with those of Laisong Formation } \\
\text { but size of Thalassinoides is found to increase comparatively. } \\
\text { Mainly Cruziana ichnofacies. Flysch sediments. }\end{array}$ \\
\hline & $\begin{array}{l}\text { Laisong } \\
(\sim 1200 \mathrm{~m})\end{array}$ & $\begin{array}{l}\text { Late Eocene/Early } \\
\text { Oligocene }\end{array}$ & $\begin{array}{l}\text { Intercalation of bedded sandstones with relatively thin siltstones } \\
\text { and shales. Conglomerate horizon in upper part. Characterized by } \\
\text { abundant trace fossils with relatively less invertebrate fossils, } \\
\text { plant/leaf fossils and very little vertebrate and invertebrate body } \\
\text { fossils. Thalassinoides, Ophiomorpha and Skolithos are dominant } \\
\text { ichnotaxa. Mainly Skolithos-Cruziana mixed ichnofacies. } \\
\text { Flysch sediments. }\end{array}$ \\
\hline \multirow[t]{2}{*}{ Disang } & $\begin{array}{l}\text { Upper } \\
\text { Disang } \\
(\sim 2000 \mathrm{~m})\end{array}$ & Late Eocene & $\begin{array}{l}\text { Intercalations of shales with relatively thin siltstones and } \\
\text { sandstones showing rhythmites. Characterized by presence of } \\
\text { certain pelecypods, gastropods, microfossils, and few trace fossils } \\
\text { like Thalassinoides and some other trails. Flysch sediments. }\end{array}$ \\
\hline & $\begin{array}{l}\text { Lower } \\
\text { Disang } \\
(\sim 2000 \mathrm{~m})\end{array}$ & Late Cretaceous & $\begin{array}{l}\text { Dark grey to black, splintery shales with virtually no vertebrate and } \\
\text { trace fossil evidence. Flysch sediments. }\end{array}$ \\
\hline \multicolumn{4}{|c|}{------------1} \\
\hline & $\begin{array}{l}\text { Ukhrul } \\
\text { limestone }\end{array}$ & Late Cretaceous & $\begin{array}{l}\text { Limestones, cherts, conglomerates characterized by abundant } \\
\text { microfossils - foraminifers and radiolarians. } \\
\text { Unconformity }\end{array}$ \\
\hline \multirow{2}{*}{\multicolumn{2}{|c|}{ Ophiolite Mélange Zone }} & $\begin{array}{l}\text { Late Cretaceous/ } \\
\qquad(?) \text { Older }\end{array}$ & $\begin{array}{l}\text { Mafic and ultramafic rocks: Ultramafic Harzburguite, Lherzolite; } \\
\text { diabasic dykes and silts; volcanic pillows, etc. }\end{array}$ \\
\hline & & ( & Unconformity - - - - - - - - - - - - - - - - - - - - - - - - - - - - \\
\hline \multicolumn{2}{|c|}{ Metamorphic Complex } & Pre-Mesozoic & \\
\hline \multirow{2}{*}{\multicolumn{4}{|c|}{ 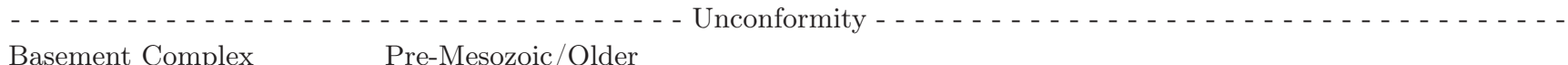 }} \\
\hline & & & \\
\hline
\end{tabular}


laminations, convolute laminations, load casts with characteristic squeezed and lineated downward protrusions, etc. The various important localities where detailed trace fossil analyses have been carried out are: (i) Tentha $\left(24^{\circ} 34^{\prime} 12.34^{\prime \prime} \mathrm{N}\right.$ and $093^{\circ}$ $\left.58^{\prime} 56.43^{\prime \prime} \mathrm{E} ; 788 \mathrm{~m}\right)$, (ii) Thongjaorok $\left(24^{\circ} 37^{\prime} 36.88^{\prime \prime}\right.$ $24^{\circ} 38^{\prime} 08.99^{\prime \prime} \mathrm{N}$ and $093^{\circ} 44^{\prime} 40.42^{\prime \prime}-93^{\circ} 44^{\prime} 28.71^{\prime \prime} \mathrm{E}$; $860-920 \mathrm{~m}$ ), (iii) Gelmon $\left(24^{\circ} 20^{\prime} 36.28^{\prime \prime} \mathrm{N}\right.$ and $093^{\circ} 39^{\prime} 43.89^{\prime \prime} \mathrm{E}$; $986 \mathrm{~m}$ ), (iv) Keithelmanbi $\left(24^{\circ} 46^{\prime}\right.$ $37.91^{\prime \prime} \mathrm{N}$ and $093^{\circ} 46^{\prime} 46.03^{\prime \prime} \mathrm{E} ; 958 \mathrm{~m}$ ), (v) Leimatak

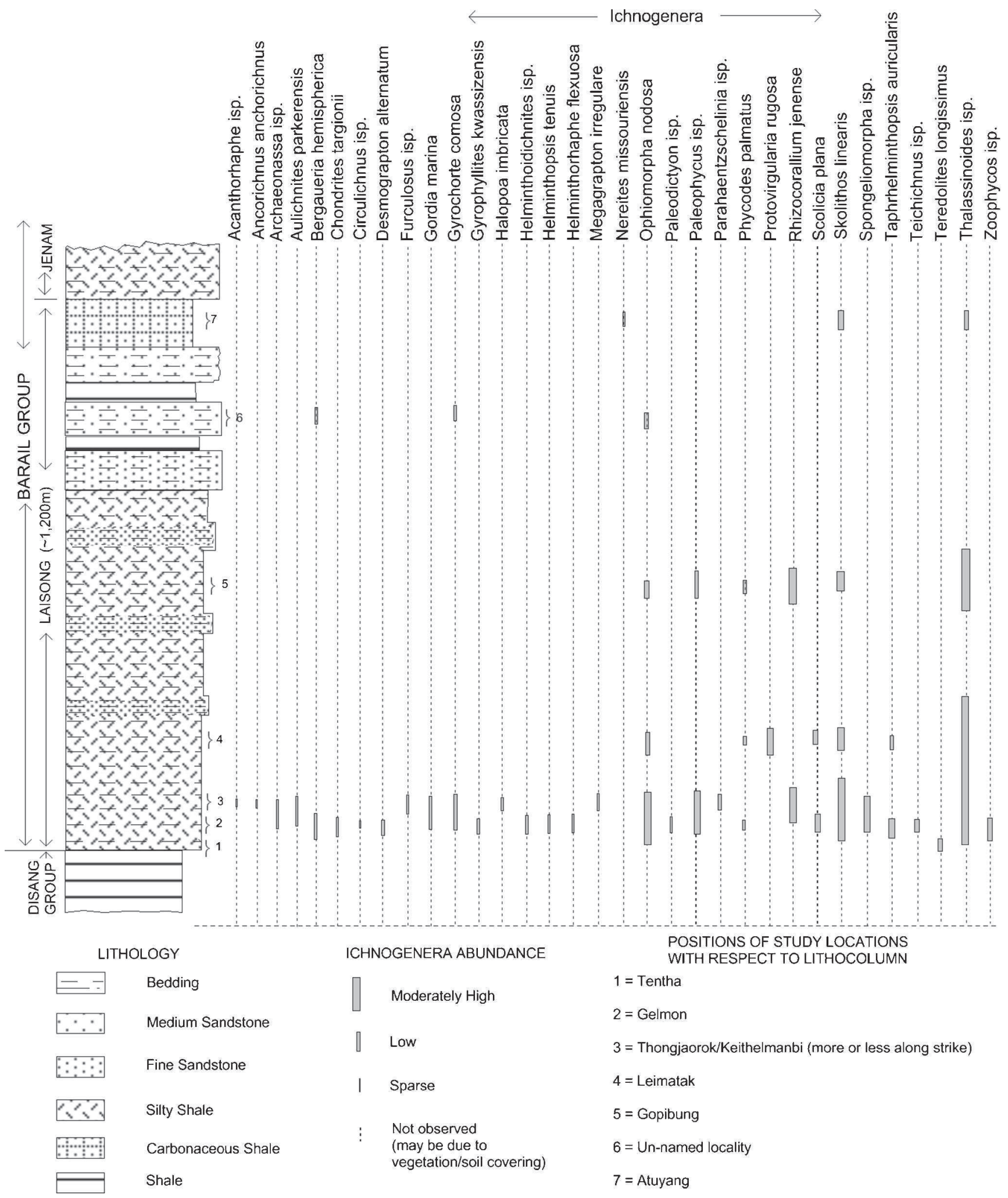

Figure 2. Generalized Laisong lithocolumn showing the vertical distribution of the various trace fossils. 


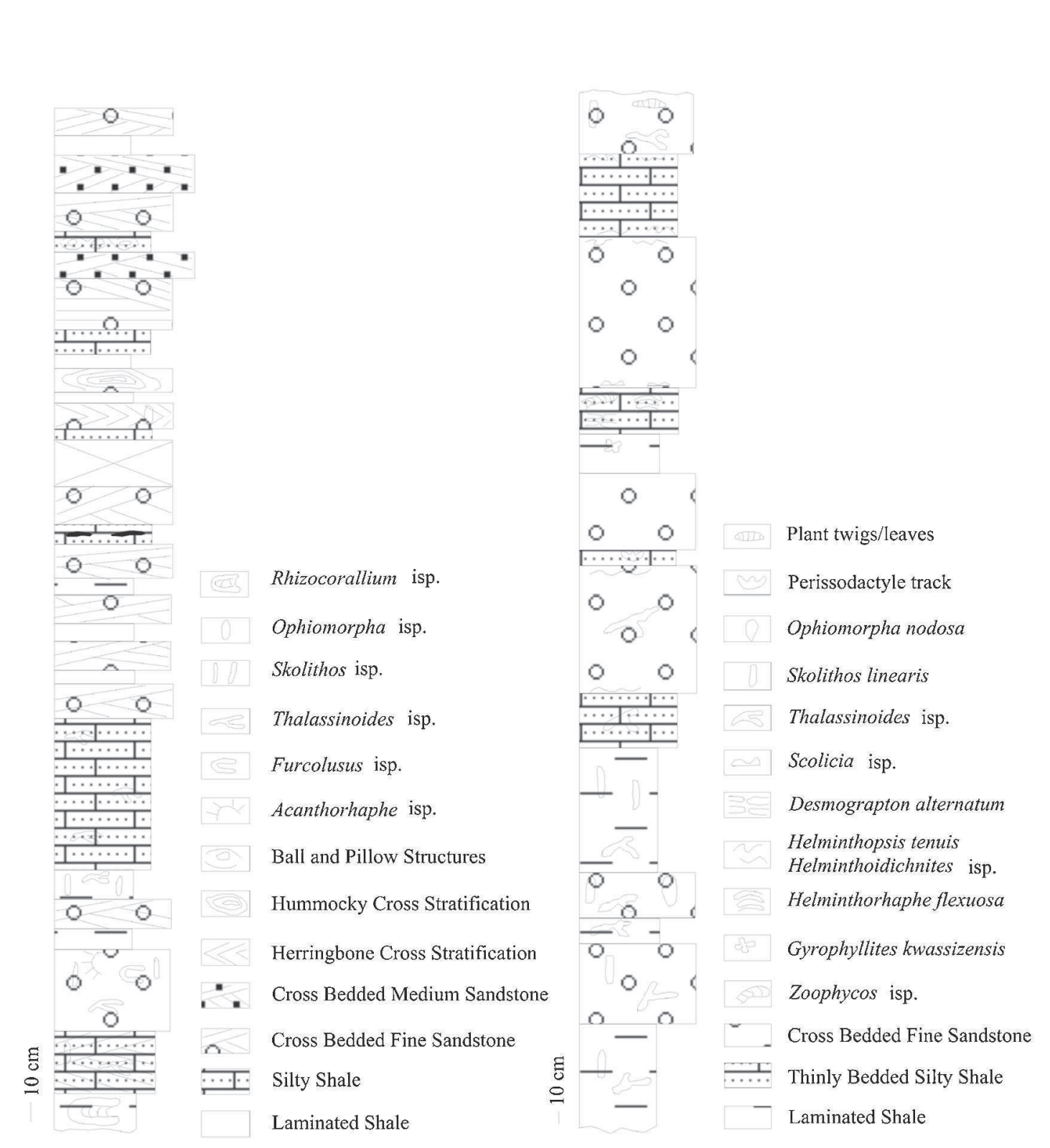

(b)

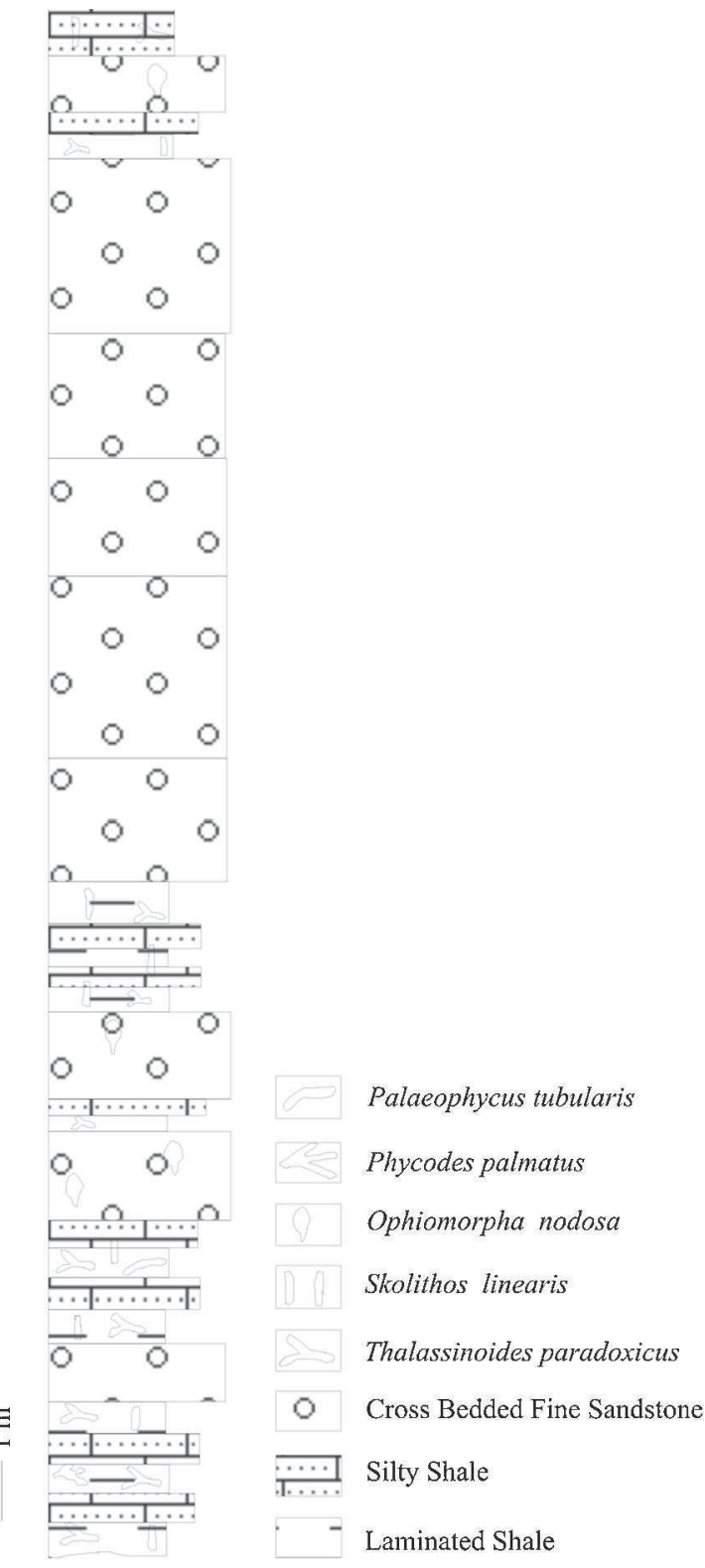

(c) 
Table 2. Sedimentology and ichnological details of the studied locations.

\begin{tabular}{|c|c|c|}
\hline Locality & Sedimentological characters & Ichnological details \\
\hline Tentha & $\begin{array}{l}\text { The rock exposure comprises of thin- to thick- } \\
\text { bedded sandstone intercalated with thin-bedded } \\
\text { siltstone beds, light grey weathered shales. Due } \\
\text { to the exposure nature, preparation of litholog } \\
\text { is not convenient. }\end{array}$ & $\begin{array}{l}\text { Teredolites longissimus and Ophiomorpha } \\
\quad \text { nodosa. }\end{array}$ \\
\hline Thongjaorok & $\begin{array}{l}\text { The lithocolumn (figure 2a) at the locality } \\
\text { represents a coarsening upward sequence. Grey } \\
\text { shale, silty shales with inclusion of fine sand- } \\
\text { stone pebbles, siltstone, fine sandstone, medium } \\
\text { sandstone, greenish colour (?glauconitic sand- } \\
\text { stone), coal streaks, etc., are the main lithologies. }\end{array}$ & $\begin{array}{l}\text { Acanthorhaphe isp., Ancorichnus ancorichnus, } \\
\text { Archaeonassa isp., Aulichnites parkerensis, } \\
\text { Chondrites targionii, Furculosus isp., Gordia } \\
\text { marina, Gyrochorte comosa, Halopoa imbricata, } \\
\text { Megagrapton isp., Ophiomorpha nodosa, } \\
\text { Parahaentzschelinia surlyki, Skolithos linearis, } \\
\text { Thalassinoides paradoxicus and Zoophycos isp. }\end{array}$ \\
\hline Gelmon & $\begin{array}{l}\text { Geologically the sediments at the section belong } \\
\text { to the basal part of Laisong Formation which is } \\
\text { at a gradational transition with the Upper Disang } \\
\text { Formation. The exposed rocks consist of tur- } \\
\text { bidites and tempestites comprising of shales, silty } \\
\text { shales, siltstones and thinly bedded to massive fine } \\
\text { sandstones. The (figure 2b) section more likely } \\
\text { represents deep marine setting in general as indi- } \\
\text { cated by structures such as parallel laminations, } \\
\text { huge load casts, massive and structureless sandstone } \\
\text { bodies, etc., in addition to the deep water related } \\
\text { ichnoassemblages. However, sedimentary features } \\
\text { such as current ripples and rain prints are also } \\
\text { present in some horizons indicating shallow sub- } \\
\text { aerial depositional environment as well. }\end{array}$ & $\begin{array}{l}\text { Aulichnites parkerensis, Chondrites targionii, } \\
\text { Circulichnus isp., Desmograpton alternatum, } \\
\text { Gordia marina, Gyrochorte comosa, Gyrophyllites } \\
\text { kwassizensis, Helminthorhaphe flexuosa, } \\
\text { Helminthopsis tenuis, Helminthoidichnites isp., } \\
\text { Ophiomorpha nodosa, Palaeodictyon maximum, } \\
\text { Palaeodictyon strozzi, Paleophycus striatus, } \\
\text { Phycodes palmatus, Scolicia isp., Skolithos } \\
\text { linearis, Taphrhelminthopsis auricularis, } \\
\text { Teichichnus isp., Thalassinoides horizontalis, } \\
\text { Thalassinoides paradoxicus and Zoophycos isp. }\end{array}$ \\
\hline Keithelmanbi & $\begin{array}{l}\text { The sediments belong to the Lower Laisong } \\
\text { Formation and consist of rhythmic successions of } \\
\text { light grey laminated shales, silty shales, siltstones } \\
\text { and thinly bedded to massive fine grained sand- } \\
\text { stones; however, the component of laminated shale } \\
\text { is more as the location is closer to Upper Disang. }\end{array}$ & $\begin{array}{l}\text { Palaeophycus tubularis, Skolithos linearis, } \\
\text { Thalassinoides paradoxicus and Spongeliomorpha } \\
\text { isp. }\end{array}$ \\
\hline Leimatak & $\begin{array}{l}\text { The section represents the middle part of Laisong } \\
\text { Formation (figure 2c). The exposed rocks consist } \\
\text { of rhythmites of shales, silty shales and thickly } \\
\text { bedded to massive fine sandstones. }\end{array}$ & $\begin{array}{l}\text { Ophiomorpha nodosa, Skolithos linearis, } \\
\text { Protovirgularia isp., Thalassinoides paradoxicus, } \\
\text { Phycodes palmatus, Paleophycus tubularis, } \\
\text { Scolicia isp. and Taphrhelminthopsis auricularis. }\end{array}$ \\
\hline Gopibung & $\begin{array}{l}\text { The sediments belong to the middle upper part of } \\
\text { Laisong Formation. The exposed rocks consist } \\
\text { of rhythmites of laminated carbonaceous shales, } \\
\text { silty shales, siltstones and thinly bedded to massive } \\
\text { fine sandstones. }\end{array}$ & $\begin{array}{l}\text { Ophiomorpha nodosa, Paleophycus striatus, } \\
\text { Paleophycus tubularis, Rhizocorallium jenense, } \\
\text { Skolithos linearis and Thalassinoides paradoxicus. }\end{array}$ \\
\hline Atuyang & $\begin{array}{l}\text { The section represents the upper part of Laisong } \\
\text { Formation. The exposed rocks consist mainly of } \\
\text { thinly laminated carbonaceous shales which are } \\
\text { intercalated with thin bed of siltstones. }\end{array}$ & $\begin{array}{l}\text { Bergaueria hemispherica, Thalassinoides } \\
\text { paradoxicus, Nereites missouriensis and } \\
\text { some trails. }\end{array}$ \\
\hline
\end{tabular}

Section $\left(24^{\circ} 36.106^{\prime}-24^{\circ} 35.544^{\prime} \mathrm{N}\right.$ and $093^{\circ} 41.870^{\prime}-$ $093^{\circ} 40.017^{\prime} \mathrm{E}$; $1151-454 \mathrm{~m}$ ), (vi) Gopibung $\left(25^{\circ} 07^{\prime}\right.$ $36.03^{\prime \prime} \mathrm{N}$ and $093^{\circ} 53^{\prime} 50.01^{\prime \prime} \mathrm{E} ; 1845 \mathrm{~m}$ ), and (vii) Atuyang $\left(24^{\circ} 48^{\prime} 06.17^{\prime \prime} \mathrm{N}\right.$ and $\left.93^{\circ} 42^{\prime} 09.74^{\prime \prime} \mathrm{E} ; 851 \mathrm{~m}\right)$ (figure 1).

\section{Rock types and occurrence of trace fossils}

The Laisong Formation is represented by a transgressive-regressive succession. The succession is more or less exclusively siliciclastic and contains a 
rich and diverse marine ichnofauna. The vertical distribution of the trace fossils are represented alongside the Laisong lithocolumn (figure 2). All the trace fossils discussed herein were collected recently and do not comprise of any specimen of earlier works; the present group of authors only worked on the presently described localities so far. As observed from the vertical distribution (figure 2 ), trace fossils are more concentrated near the basal part of the Laisong Formation. This is possibly due the lack of exposures in other parts of the succession. The Thongjaorok, Gelmon and Leimatak are the three best exposed sections and figure 3 ( $\mathrm{a}, \mathrm{b}$ and $\mathrm{c}$ ) respectively represents the lithologs detailing trace fossils and sedimentological features at these three sections. The sedimentological and ichnological details of the different studied sections are also represented by table 2 .

\section{Systematic ichnology}

Identification procedure of the herein described ichnofossils is followed after the Treatise on Invertebrate Paleontology (Häntzschel 1962, 1975) and for classification of the traces into two broad categories as pre- and post-depositional, the classification schemes of Seilacher (1962, 1977b) and Uchman and Wetzel (2011) are followed. Altogether 36 ichnospecies belonging to 33 ichnogenera have so far been identified (table 3 ).

\subsection{Pre-depositional traces}

The pre-depositional trace fossils are the result of successional colonization (Leszczyński 1993); this assemblage is rich in graphoglyptids and grazing trails, and feeding structures. The ichnodiversity, ethology, and morphologic complexity of the predepositional association are indicative of the Nereites ichnofacies (Seilacher 1964). The trace fossils of pre-depositional origin were produced in the hemipelagic facies underlying the turbidite bed (Seilacher 1977b). Quiet, stable conditions prevailed during this period without the influence of turbidites and with only small changes in the environmental factors (Frey and Pemberton 1984). The organisms that lived in such an environment had enough time to rework the sediment (Wetzel 1991). They are common on the soles of turbiditic sandstones, but never abundant. They are preserved mostly as semi-reliefs resulting from scouring and casting of shallow burrow systems. Their tubes are mostly less than $2 \mathrm{~mm}$ wide (Uchman and Wetzel 2011).

Ichnogenus: Bergaueria Crimes, Legg, Marcos and Arboleya 1977

Ichnospecies: Bergaueria hemispherica Crimes, Legg, Marcos and Arboleya 1977 (figure 4a)

Materials: Three specimens preserved in fine sandstone were collected (MIMB - 1 to 3 ) and more field observations at $24^{\circ} 48^{\prime} 02^{\prime \prime} \mathrm{N}$ and $93^{\circ} 42^{\prime} 18^{\prime \prime} \mathrm{E}$ (an unnamed locality).

Description: Typically knob-shaped, hypichnial mound on lower surface of sandstone beds, with hemispherical terminations, vertically arranged, oval to circular in outline with $14-20 \mathrm{~mm}$ diameter and $4-7 \mathrm{~mm}$ height; the sandy fill is essentially structureless.

Remarks: Bergaueria hemispherica is predepositional. It is either domichnia or cubichnia of shallow burrows or casts of upper part of deeper vertical burrows (Leszczyński 2004). Probably produced by suspension-feeders such as sea-anemones; also indicative of normal marine conditions on a wave- or tide-dominated shoreface and in flysch

Table 3. Toponomic classification of Laisong traces.

\begin{tabular}{ll}
\hline Forms & \multicolumn{1}{c}{ Ichnospecies } \\
\hline Endichnia & Ancorichnus ancorichnus, Chondrites targionii, Ophiomorpha nodosa, \\
& Palaeophycus tubularis, P. striatus, Parahaentzschelinia surlyki, \\
& Phycodes palmatus, Rhizocorallium jenense, Skolithos linearis, \\
& Spongeliomorpha isp., Teichichnus isp., Thalassinoides paradoxicus, \\
& T. Horizontalis and Zoophycos isp. \\
Epichnia & Archaeonassa isp., Aulichnites isp., Circulichnus isp., Gyrochorte \\
& comosa, Gyrophyllites kwassizensis, Helminthopsis tenuis, Proto- \\
& virgularia rugosa and Nereites missourensis. \\
Hypichnia & Acanthorhaphe isp., Bergaueria hemispherica, Desmograpton alter- \\
& natum, Furculosus isp., Gordia marina, Halopoa imbricata Helmin- \\
& thoidichnites isp., Helminthorhaphe flexuosa, Megagrapton isp., \\
& Palaeodictyon maximum, P. strozzi, Scolicia strozzi and Taphr- \\
& helminthopsis auricularis.
\end{tabular}



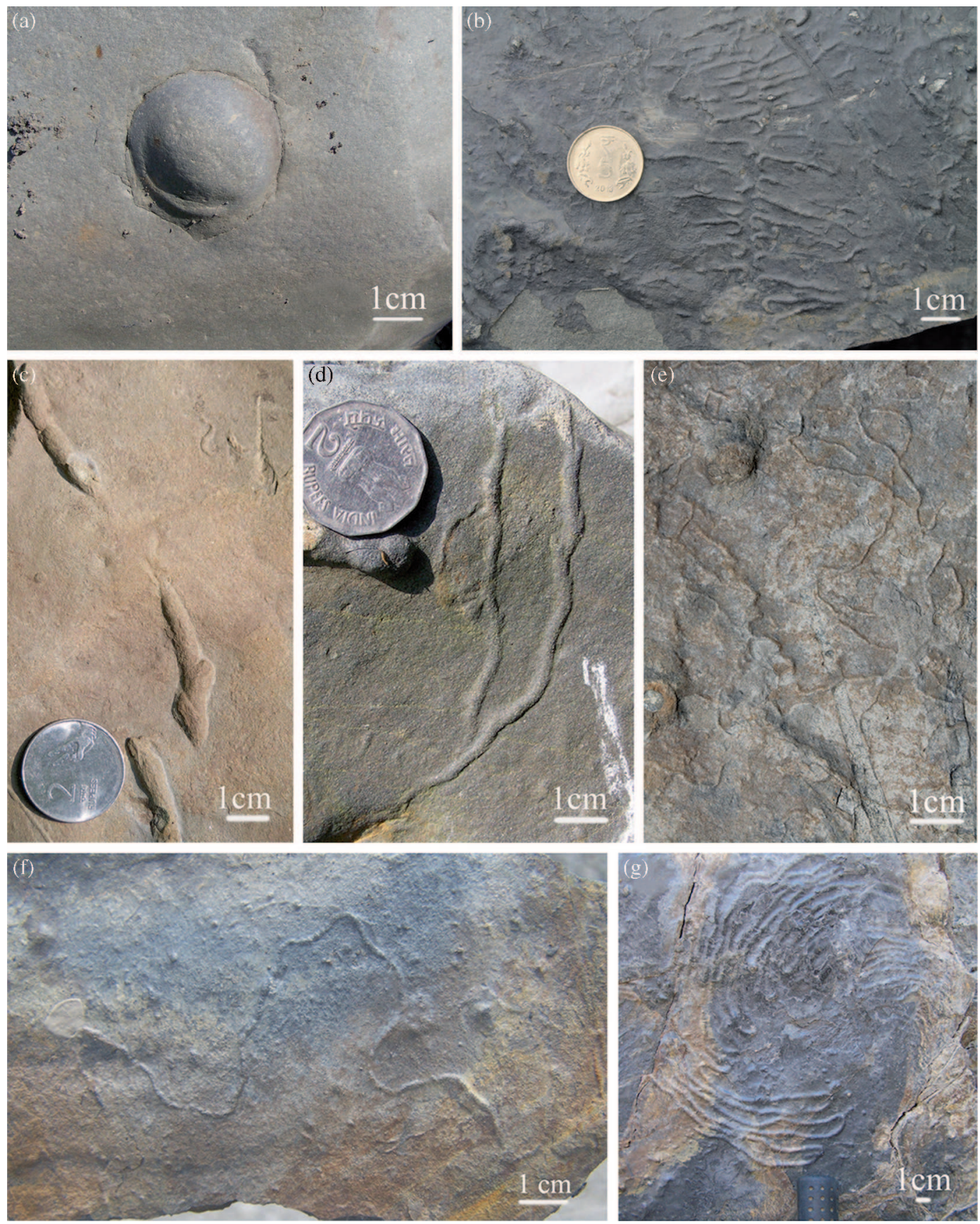

Figure 4. (a) Bergaueria hemispherica, in fine sandstone at $24^{\circ} 48^{\prime} 02^{\prime \prime} \mathrm{N}$ and $93^{\circ} 42^{\prime} 18^{\prime \prime} \mathrm{E}$ (an unnamed locality). (b) Desmograpton alternatum, in the sole of thin fine sandstone from Gelmon. (c and d) Halopoa imbricata, in thick-bedded fine sandstone, Thongjaorok locality. (e) Helminthoidichnites isp. in sole of thin bedded fine sandstone, Gelmon. (f) Helminthopsis tenuis, in sole of very fine sandstone, Gelmon. (g) Helminthorhaphe flexuosa, in sole of thin-bedded shale, Gelmon.

deposits; common element of the Skolithos ichnofacies in brackish water environments, but greatly reduced in size (Uchman 1995).

Ichnogenus: Desmograpton Fuchs 1895

Ichnospecies: Desmograpton alternatum Książkiewicz 1977 (figure 4b)

Materials: Three specimens collected from Gelmon (MIMD - 1 to 3), which were found preserved on the sole of thin fine sandstone.
Description: Hypichnial double rows of meandered strings shaped like $\mathrm{U}$ or $\mathrm{J}$ and of moderate width, elevated in the curved portions. The connecting bars are obliquely oriented to the trace fossil axis and form a zig-zag pattern (cf. Uchman 1995). Remarks: Desmograpton isp. is interpreted as threedimensional graphoglyptid trace fossils (Seilacher 1977a). It occurs in flysch deposits from the Silurian (McCann 1989, 1993) to the Miocene (D'Alessandro 1980; Uchman 1995). Desmograpton alternatum 
indicates the development of the traces immediately before the turbiditic event (Monaco and Cecconi 2010).

Ichnogenus: Halopoa Torell 1870

Ichnospecies: Halopoa imbricata Torell 1870 (figure 4c and d)

Materials: Three specimens from a thick-bedded, fine sandstone were collected from Thongjaorok locality (MIMHalo -1 to 3 ).

Description: Horizontal, straight, pre-depositional, hypichnial burrows that show more or less distinctive longitudinal, irregular, imperfectly overlapping wrinkles and furrows of different sizes. They are 6-8 $\mathrm{mm}$ in cross-section. The specimens have short and abrupt branches and the ridges are intercrossing and interpenetrating (Uchman 1998).

Remarks: The burrows are recorded on soles of sandstone turbidite beds that rest on shale/mudstone possibly produced by deposit-feeding organisms (worms). They have a long geological range, Cambrian-Recent.

Ichnogenus: Helminthoidichnites Fitch 1850

Ichnospecies: Helminthoidichnites isp. Fitch 1850 (figure 4e)

Materials: Two specimens collected from Gelmon (MIMHe - 1 and 2) and more than 40 specimens noted at Gelmon; three specimens observed at $24^{\circ} 48^{\prime} 02^{\prime \prime} \mathrm{N}$ and $93^{\circ} 42^{\prime} 18^{\prime \prime} \mathrm{E}$. They are occurring in the sole of thin-bedded fine sanstone.

Description: Small, simple and unbranched, winding traces preserved as positive hyporeliefs. The traces are about 1-3 $\mathrm{mm}$ wide with maximum length (as measured on the bedding plane) of about $15 \mathrm{~mm}$. The structures are mainly horizontal and curvy with a few self-overcrossings.

Remarks:Helminthoidichnites differs from Gordia by lack of self-overcrossing (Kim et al. 2002). It is interpreted as a pascichnia produced in shallow tiers by vagile tracemakers. The ichnogenus has been reported from deep marine settings (Buatois and Mángano 2003).

Ichnogenus: Helminthopsis Książkiewicz 1968 Ichnospecies: Helminthopsis tenuis Książkiewicz 1968 (figure 4f)

Materials: Three specimens found in the sole of very fine sandstone were collected from Gelmon (MIMHelm - 1 to 3) and a few more field observations. Description: Specimens display straight segment separated by irregular loose horizontal, smooth, unbranched, convex, unlined meandering trails or burrows. Diameter varies from 1.0 to $1.5 \mathrm{~mm}$ but is constant within each specimen; maximum length is $65 \mathrm{~mm}$ and width is about $4 \mathrm{~mm}$; preserved in fine-grained turbidite sandstones.
Remarks: Irregular meander with greater sinuosity differentiates the specimens from Helminthoidichnites (Hofmann and Patel 1989) and from Gordia by its lack of self-overcrossing and the tendency to meander (Pickerill 1981). Helminthopsis tenuis is interpreted to represent a grazing trail produced by a deposit-feeding organism (Buatois et al. 1998); common in deep-marine deposits, but also observed in shallow-marine environments (Kim et al. 2005).

Ichnogenus: Helminthorhaphe Uchman 1995

Ichnospecies: Helminthorhaphe flexuosa Uchman 1995 (figure 4g)

Materials: Three specimens associated with thin bedded shale were collected from Gelmon (MIMHelmi - 1 to 3 ).

Description: Convex hyporelief trails consisting of strings, which form narrow and high amplitude meanders which are numerous, regular to irregular and parallel to unparallel; closely spaced, with trail width of about 3-4 $\mathrm{mm}$ and meander length of 150 $\mathrm{mm}$. The distance between the meanders is $2-3$ times the diameter of the string. The surface of the string is smooth and no longitudinal striations or transverse riblets are seen. Bulges in the turning portion are very rare and poorly expressed.

Remarks: Helminthorhaphe flexuosa is known from the fan fringe deposits of the Eocene turbiditic Cingöz Formation (Uchman and Demircan 1999; Demircan and Toker 2004). The ichnospecies has also been described from the Eocene Kusuri Formation (Uchman et al. 2004).

Ichnogenus: Megagrapton Książkiewicz 1968 Ichnospecies: Megagrapton irregulare Książkiewicz 1968 (figure 5a)

Materials: Two specimens observed in thinbedded very fine sandstone at Thongjaorok.

Description: Branching and winding strings with diameter of $5 \mathrm{~mm}$ and width of 0.5-1.4 mm. Angles of branching is commonly acute and to some extent right angles. The main ridges are up to $30 \mathrm{~mm}$ long. Burrow lining not detected.

Remarks: Megagrapton irregulare is a distinctive graphoglyptid trace fossil (Seilacher 1977a), which is almost universally preserved as a positive feature in convex hyporelief on bedding plane soles. Irrespective of origin, the trace can be clearly assigned to Megagrapton irregulare, which is characterized by its irregular shaped polygonal nets of different sizes and common right angle branches at irregular intervals (Książkiewicz 1977). The ichnogenus is typical deep-water form.

Ichnogenus: Palaeodictyon Meneghini 1850 in Savi and Meneghini 1850

Ichnospecies: Paleodictyon cf. maximum Eichwald 1868 (figure 5b) 

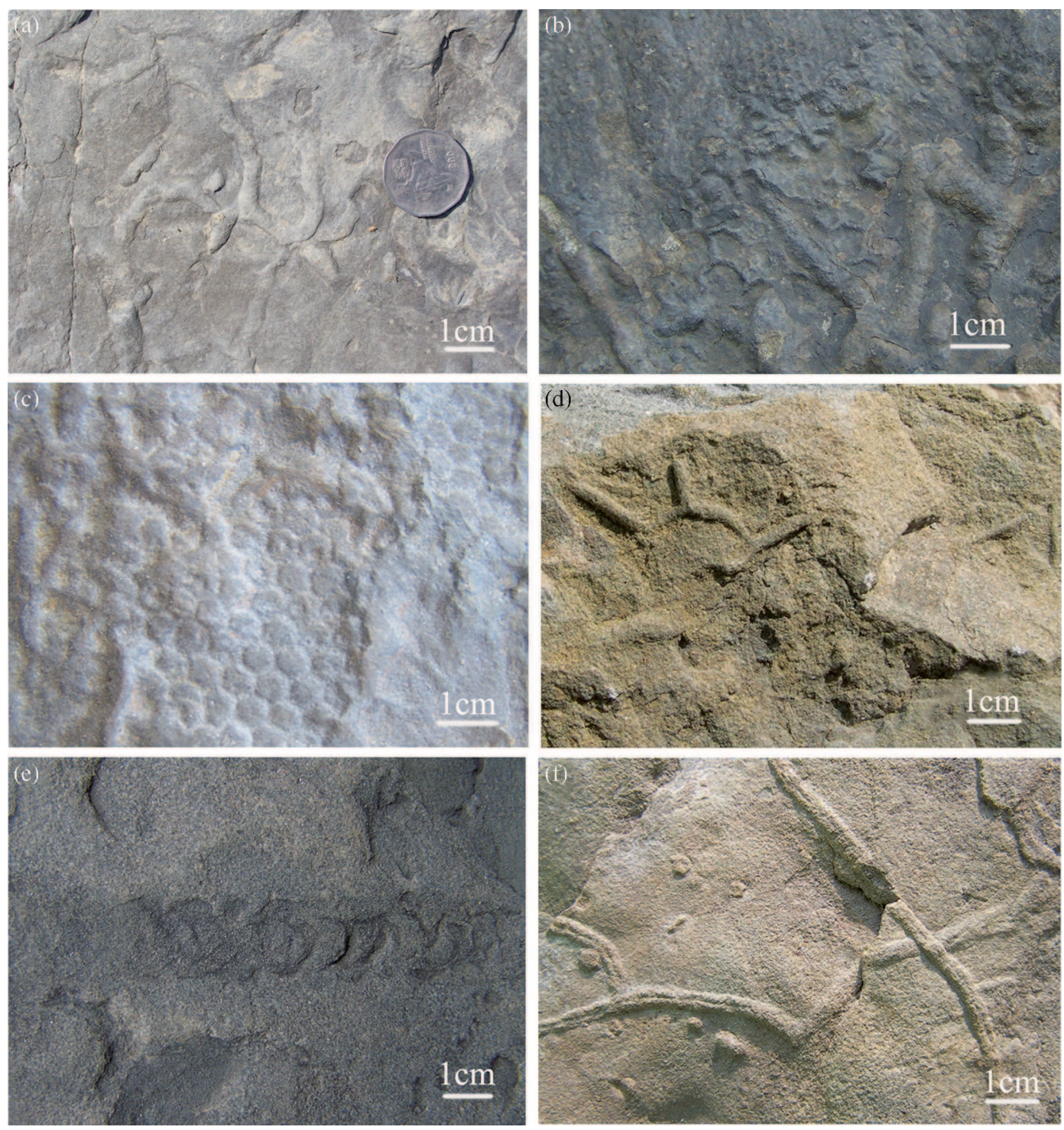

Figure 5. (a) Megagrapton isp. in thin-bedded very fine sandstone, Thongjaorok. (b) Paleodictyon cf. maximum, in sole of thin-bedded very fine sandstone, Gelmon. The traces are seen associated with Thalassinoides isp. (c) Paleodictyon strozzi, in the sole of thin, very fine sandstone, Gelmon. (d) Acanthorhaphe isp. in a 30-cm thick fine sandstone bed, Thongjaorok. (e) Ancorichnus ancorichnus in massive fine sandstone, Thongjaorok. (f) Archaeonassa isp. in thin-bedded fine sandstone, Thongjaorok.

Materials: Two specimens found preserved on sole of thin-bedded, very fine sandstone were collected (MIMPm-1 and 2) and eight more specimens observed at Gelmon.

Description: The maximum mesh size (MMS) ranges from 8-10 $\mathrm{mm}$ and the bordering riblets/string diameter (SD) between 1 and $1.7 \mathrm{~mm}$. The nets are of moderate size and more or less of hexagonal shape and are preserved as semi-relief on the sole of fine-to-medium sandstone. Seilacher (1977a) proposed sub-ichnogeneric names for Palaeodictyon as: (1) Glenodictyum to indicate only horizontal hexagonal meshes, (2) Ramodictyon when vertical shafts are preserved, and (3) Squamodictyon to indicate scale like meshes. The described specimens are showing only horizontal hexagonal meshes so they may belong to ichnogenera Glenodictyon.

Remarks: According to the classification scheme of Uchman (1995), which uses string diameter and mesh diameter as diagnostic criteria, the trace may belong to $P$. maximum. Solitary burrowers, colonial burrowers, nonburrowing protists or multicellular organisms, organisms feeding in their burrow system on cultivated or trapped micro-organisms have been some of the suggested organisms responsible for the specimens (Uchman 1995; Honeycutt and Plotnick 2005). Książkiewicz (1977) observed that most of the Palaeodictyon isp. producers lived and worked below sand layers, but some were able to live in mud, and probably to ingest both mud and fine-grained sand. Palaeodictyon isp. is a typical 
deep-water graphoglyptid, mostly in flysch sediments, and usually of Nereites ichnofacies. However, Uchman (1995) indicated the presence of Palaeodictyon isp. in shallow-water deposits, and the problematic occurrence in freshwater sediments.

Ichnogenus: Palaeodictyon Meneghini 1850 in Savi and Meneghini 1850

Ichnospecies: Palaeodictyon strozzi Meneghini 1850 in Savi and Meneghini 1850 (figure 5c)

Materials: Seven specimens collected (MIMPs 1 to 7 ) with more field observations at Gelmon occurring on the sole of thin-bedded, very fine sandstone.

Description: The maximum mesh size (MMS) ranges from $3-5 \mathrm{~mm}$ and the bordering riblets/ string diameter (SD) between 0.2 and $0.8 \mathrm{~mm}$. The nets are of moderate size and more or less of hexagonal shape and are in semi-relief on the sole of fine-to-medium sandstone. The horizontal nature of the hexagonal meshes indicates that the described specimens belong to ichnogenera Glenodictyon.

Remarks: Similar remarks may be assigned for Palaeodictyon strozzi as that of P. maximum.

\subsection{Post-depositional traces}

The quiet stable conditions prevailed during the development of pre-depositional traces were interrupted abruptly by turbidity currents and the newly deposited sediments established an environment suitable for more opportunistic, less stable fauna (Seilacher 1977b; Frey and Seilacher 1980). The trails produced by these opportunistic organisms that flourished in a relatively short period after the turbidite depositions are classified as post-depositional trace fossils. The post-depositional association essentially consists of dwelling and feeding traces. They occur as endichnial structures according to the toponomic classification of Martinsson (1970). The post-depositional association mainly includes elements of the Skolithos ichnofacies (cf. Uchman and Wetzel 2011).

\section{Ichnogenus: Acanthorhaphe Książkiewicz 1977}

Ichnospecies: Acanthorhaphe isp. Książkiewicz 1977 (figure 5d)

Materials: Two specimens collected from Thongjaorok.

Description: Small arcuate strings having uniform diameter of about $1.5 \mathrm{~mm}$ and a length of $10-20 \mathrm{~mm}$. Numerous thorn-like appendages are present on the convex side of the string. The strings have to some extent a semi-circular curvature with no straight segment; preserved as hypichnial burrow.

Remarks: The appendages of the herein described specimens are nearly uniform in diameter thus differing from $A$. delicaluta and $A$. incerta where the appendages are narrowed at the base and pointed at the outer end; string diameter is slightly more than $1 \mathrm{~mm}$ in the described specimens but less than $1 \mathrm{~mm}$ in $A$. delicaluta and A. incerta. As only two specimens were observed it is difficult to assign them to a new ichnospecies. The studied ichnospecies, however, is very close to $A$. delicatula (Ksiazkiewicz 1977). Acanthorhaphe isp. marked specialised strategies that were developed in response to depleted food conditions and absence of sunlight. That is, the animals which are responsible for such traces have the behaviour for cultivation of microbes or construction of structures that served as traps of microbes. This is a good adaptation of oligotrophic environments, with incidental food supply and high competition for gathering of food. They are typical of base of slope environments such as deep water turbidites (flysch deposits) (Seilacher 2007).

Ichnogenus: Ancorichnus Heinberg 1974

Ichnospecies: Ancorichnus ancorichnus Heinberg 1974 (figure 5e)

Materials: Three specimens observed in massive fine sandtone at Thongjaorok.

Description: Horizontal, unbranched, winding cylindrical full relief burrows having gentle annulations on the surface. Width of burrow is approximately $17 \mathrm{~mm}$, and thickness of the mantle varies between 3 and $4 \mathrm{~mm}$; spacing between successive menisci is about $2-3 \mathrm{~mm}$. Course of burrow is slightly undulating and subparallel to the bedding plane. The core is slightly darker than the outer layer.

Remarks: Heinberg (1974) and Heinberg and Birkelund (1984) related Ancorichnus isp. to locomotion of an infaunal soft-bodied organism such as priapulids, siphunculids, or ethologically equivalent worms. The presence of a mantle distinguishes Ancorichnus from morphologically similar ichnogenera such as Beaconites. Ancorichnus has been documented from lower offshore depositional environment (MacEachern and Pemberton 1992).

Ichnogenus: Archaeonassa Fenton and Fenton 1937 Ichnospecies: Archaeonassa isp. Fenton and Fenton 1937 (figure 5f)

Materials: Three specimens observed in thinbedded fine sandstone at Thongjaorok.

Description: Simple, horizontal, unbranched, straight to curved or gently winding trail constituted by two symmetrical lobes separated by a central furrow, preserved as positive epirelief. Width of the structures is $6-16 \mathrm{~mm}$.

Remarks: Archaeonassa is a poorly known ichnogenus which is a member of the Scolicia group. The ichnotaxonomic status of Archaeonassa is still debated (Yochelson and Fedonkin 1997); usually interpreted as a pascichnia produced by arthropods and mollusks (Mángano et al. 2005). Archaeonassa has 

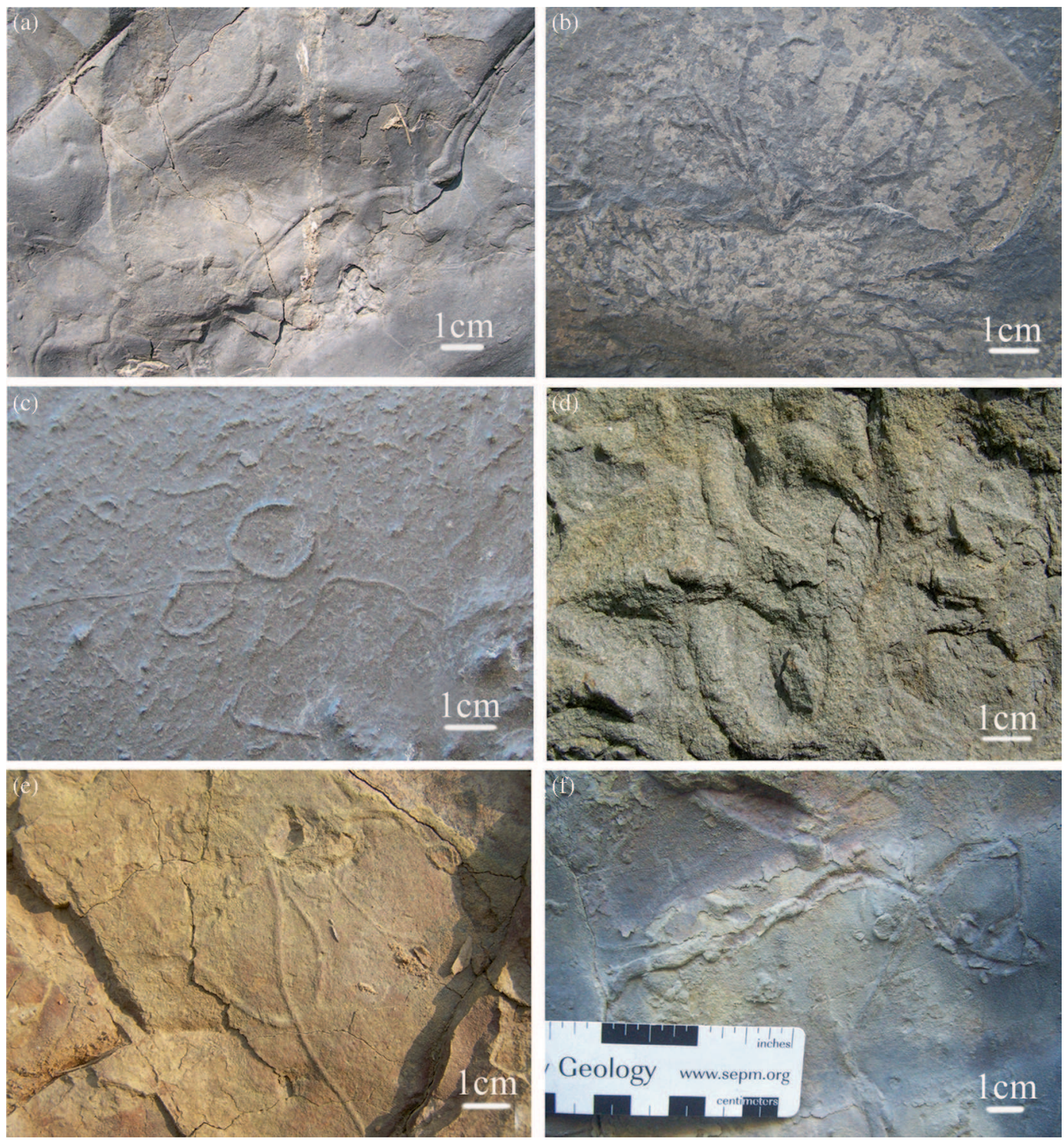

Figure 6. (a) Aulichnites parkerensis in wave rippled fine sandstone surface, Thongjaorok. (b) Chondrites targionii in very fine sandstone, Gelmon. (c) Circulichnus isp. in the sole of siltstone bed, Gelmon. (d) Furculosus isp. in medium grained massive and highly bioturbated sandstone, Thongjaorok. (e) Gordia marina in weathered silty shale, Thongjaorok. (f) Gyrochorte comosa in fine sandstone at $24^{\circ} 48^{\prime} 02^{\prime \prime} \mathrm{N}$ and $93^{\circ} 42^{\prime} 18^{\prime \prime} \mathrm{E}$ (an unnamed locality).

been reported from floodplain deposits (Buatois and Mangano 2002). The ichnogenus is interpreted chiefly as the work of gastropods in proximity of the sediment/water interface; may also have been produced by echinoids, and represent the exogenic expression of either surface or shallow subsurface locomotion.

Ichnogenus: Aulichnites Fenton and Fenton 1937 Ichnospecies: Aulichnites parkerensis Fenton and Fenton 1937 (figure 6a)

Materials: Twenty specimens found occurring in fine sandstone at Gelmon and 15 specimens observed in wave-rippled fine sandstone surface from Thongjaorok.

Description: The trails are 5-8 mm wide, strongly curved, in general. The two convex ridges are smooth and separated by rather deep median groove. Surfaces of the ridges are flattened.

Remarks: Sinuosity, shape, size and trails closely approaches Aulichnites. It has been interpreted as crawling and/or grazing trails, most probably made by gastropods or arthropods (Kumar and Pandey 2008). Gong (1999) proposed clams as the producers of Aulichnites parkerensis. Aulichnites has been associated with shallow marine environment (Frey and Howard 1990).

Ichnogenus: Chondrites Brongniart 1828

Ichnospecies: Chondrites targionii Brongniart 1828 (figure $6 \mathrm{~b}$ )

Materials: Three specimens collected from Gelmon (MIMCh -1 to 3 ), which are associated with very fine sandstone. 
Description: The structures consist of a network of filled burrows which are branching regularly and occur as en masse. First order branches dominate. The angle of branching is usually sharp. Most of the tunnels are more or less straight, radiating with average width of $3 \mathrm{~mm}$ and length ranging between 20 and $60 \mathrm{~mm}$; longest tunnel is about $100 \mathrm{~mm}$.

Remarks: The size and shape of the specimens are in the range of Chondrites targionii described by Uchman (1999). Tracemaker is able to live at the oxic/anoxic interface, in dysaerobic conditions, as a chemosymbiont ( $\mathrm{Fu}$ 1991). In the studied section, Chondrites appear sparsely. The high degree of branching suggests construction by endobenthic deposit feeders. Simpson (1957) presumes the unsegmented 'worms' like siphunculids as the producers, but Schäfer (1972) relates Chondrites to recent polychaete forms.

Ichnogenus: Circulichnus Vyalov 1971

Ichnospecies: Circulichnus isp. Vyalov 1971 (figure 6c) Materials: Five specimens observed in siltstone bed at Gelmon.

Descriptions: Circular, ring-shaped, unlined trace on bedding plane. Outer diameter is $10-15 \mathrm{~mm}$ and burrow is about $1-1.5 \mathrm{~mm}$ thick.

Remarks: The Laisong specimen is considerably close to the type specimen described by Vyalov (1971). Closely resembles in shape and size to $C$. montanus described from Carboniferous lacustrine deposits of Argentina by Buatois and Mángano (1993). C . montanus is a feeding structure (fodinichnia) probably produced by vermiform animals. Fillion and Pickerill (1984) regarded them as marginal marine, eurybathic ichnotaxon.

Ichnogenus: Furculosus Roniewicz and Pienkowski 1977

Ichnospecies: Furculosus isp. Roniewicz and Pienkowski 1977 (figure 6d)

Materials: Ten specimens collected (MIMF - 1 to 10) from medium-grained, massive and highly bioturbated sandstone and more field occurrences at Thongjaorok.

Description: Horizontal to sub-horizontal tubes, circular in outline, smooth, unlined and up to $6 \mathrm{~mm}$ in diameter. The distance between the two limbs is usually $18-20 \mathrm{~mm}$ and the length of the tubes reaches up to $50 \mathrm{~mm}$.

Remarks: Trace fossil Furculosus isp. is one of the four genera which are U-shaped. The four ichnogenera are Diplocraterion, having a vertical U-structure and spreite; Rhizocorallium, composed of a sub-horizontal spreiten U-structure; Arenicolites, showing a vertical U-structure without spreite; and Furculosus, showing a sub-horizontal or oblique ' $U$ ' without spreite; they could have been made by suspension feeding/dwelling animals (Mikuláš et al. 2004). They are characteristic of settings with strong wave and current energy, but have been registered in different facies from flysch successions to fine-grained rocks and hemipelagic limestones (Mikuláš et al. 2004; Chen et al. 2011).

Ichnogenus: Gordia Emmons 1844

Ichnospecies: Gordia marina Emmons 1844 (figure 6e)

Materials: Three specimens each collected from silty shale at Thongjaorok (MIMGo - 1 to 3) and Gelmon (MIMGo -4 to 6 ) with more field occurrences.

Description: Studied specimens appear as thin (0.6-1.0 $\mathrm{mm})$ and discontinuous hypichnial string. The shape is semi-arcuate, with many thin traces disposed in different directions and commonly overlapping each other.

Remarks: The trace is a thin surface trail or shallow sub-surface burrow characterized by overcrossing and looping which is not as intense as in Mermia. The presence of overcrossing distinguishes it from Helminthoidichnites and Helminthopsis (Buatois et al. 1998). The ichnospecies is assigned to Gordia marina, which is one of the four ichnospecies of Gordia that are considered valid (Buatois et al. 1998). Several tracemakers have been assigned to Gordia according to the environment; see Uchman et al. (2009) for a detailed review.

\section{Ichnogenus: Gyrochorte Heer 1865}

Ichnospecies: Gyrochorte comosa Heer 1865 (figure 6f) Materials: Three specimens each collected from Thongjaorok (MIMGy - 1 to 3) and Gelmon (MIMGy -4 to 6 ) in fine sandstone and more field occurrences at these two sections and $24^{\circ} 48^{\prime} 02^{\prime \prime} \mathrm{N}$ and $93^{\circ} 42^{\prime} 18^{\prime \prime} \mathrm{E}$ (an unnamed locality).

Description: Burrows are in the form of bilobate, horizontal traces, $4-6 \mathrm{~mm}$ wide and up to $3 \mathrm{~mm}$ high above bedding plane. Interpenetration of burrows is common. The three-dimensional patterns of the burrows within the sediments has not been observed. The herein described specimens have indistinct pads and the delicate internal structure corresponding to oblique spreiten has been not recognized. The specimens are similar to those illustrated by Fürsich et al. (2006) and assigned to Gyrochorte comosa.

Remarks: Gyrochorte has been reported from India by Ghare and Kulkarni (1986) and Patel et al. (2008). They are commonly interpreted as traces of animal-like polychaeate worm passing through the sediment in inclined position, selecting sediment for food over the entire length of its body. The sediment was transported backward along the body by the animal as documented by ridges on bedding planes (Heinberg 1973). According to de Gibert and Benner (2002), the tracemaker 

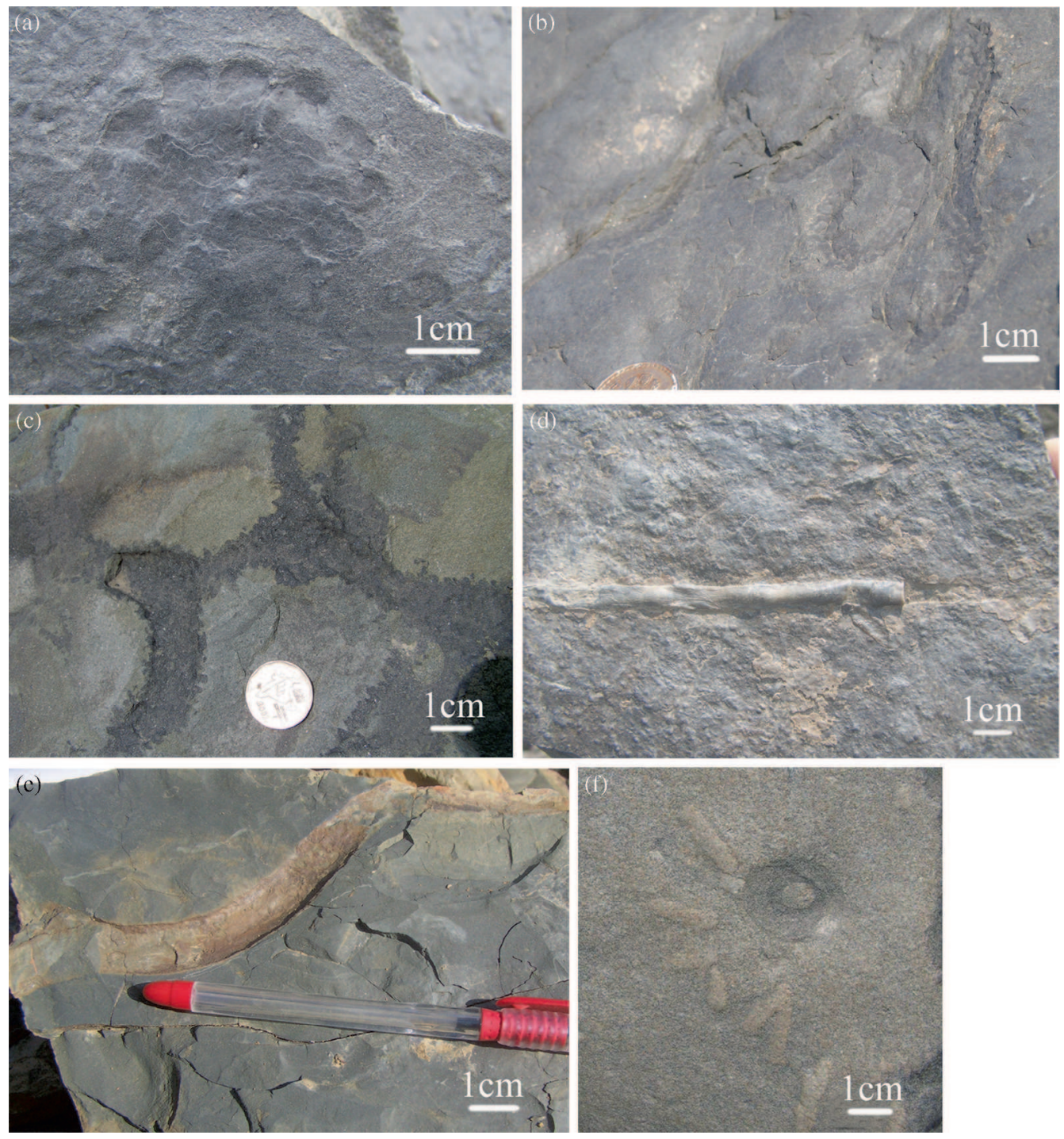

Figure 7. Gyrophyllites kwassizensis preserved in thin $(4 \mathrm{~cm})$ silty shale bed, Gelmon. (b) Nereites missouriensis in waverippled silty shale bed, Atuyang. (c) Ophiomorpha nodosa in medium-grained sandstone, Leimatak. (d) Palaeophycus striatus, observed in fine sandstone at Thongjaorok. (e) Palaeophycus tubularis observed in shale and silty shale at Keithelmanbi. (f) Parahaentzschelinia surlyki in fine sandstone at Thongjaorok.

must have been a detritus-feeding annelid with an opportunistic strategy for colonizing sandy bottoms after high energy event deposition.

Ichnogenus: Gyrophyllites Glocker 1841

Ichnospecies: Gyrophyllites kwassizensis Gloker 1841 (figure 7a)

Materials: Two specimens collected from Gelmon locality (MIMGyro - 1 and 2) found preserved in thin $(40 \mathrm{~mm})$ silty shale bed.

Description: The rosetted structures comprised of 12 closely spaced leaf-like furrows. Diameter of the rosette is about $40 \mathrm{~mm}$ and the radiating lobes are up to $5-6 \mathrm{~mm}$ wide with the distal margin of the rosette rounded; the central shaft has a diameter of about $2-3 \mathrm{~mm}$. The structures are lined with dark argillaceous substance.
Remarks: The specimens described have close affinity with $G$. kwassizensis. The central shaft of stellate trace fossils is generally regarded as the burrow where the tracemaker lived (Häntzschel 1970), and from which the radial tunnels were constructed and refilled, probably in search for food. The burrow is designated as a fodinichnion of polychaetes. The stem or shaft of the burrow may mark the path of the animal, when it left one rosette-like burrow for another place to dig by means of the proboscis, which dug sideways and descending until it reaches a firmer or coaser sand layer, presumably also poorer in food. They are found on the muddy tops, rather than on the sandy soles, of flysch turbidites (Książkiewicz 1977).

Ichnogenus: Nereites Weller 1899 
Ichnospecies: Nereites missouriensis Weller 1899 (figure 7b)

Materials: Four specimens collected from Atuyang $\left(24^{\circ} 48^{\prime} 06.17^{\prime \prime} \mathrm{N}\right.$ and $\left.93^{\circ} 42^{\prime} 09.74^{\prime \prime} \mathrm{E}\right)$ (MIMNe-1 to 4$)$. The specimens are associated with wave-rippled silty shale bed.

Description: The specimen is irregularly curved with deep smooth-walled dimples, horizontal and unbranched. Chain restricted in length. Some menisci are separated by sandy films. The width of the meniscate filling is between 3 and $4 \mathrm{~mm}$. The exterior of the trails present a well developed chain of closely packed sediment pustules. The total width of the burrow is $\sim 10 \mathrm{~mm}$ and the maximum preserved length is $\sim 180 \mathrm{~mm}$. The menisci are poorly distinguishable; distance between which is not constant and relatively small.

Remarks: The ichnogenus Nereites include diverse winding and meandering traces of different ichnotaxa (Uchman 1995). The specimens studied are small in size and have been interpreted as the work of a worm-like, deposit feeder (Häntzschel 1975) or other organisms such as mollusks, arthropods, or holothuroids (Rindsberg 1994). If organic matter deposition increased, the oxygen flux into the sediment is lowered and the producers of Nereites respond; they are quite sensitive to oxygenation within the sediment while feeding about $10 \mathrm{~mm}$ above the redox boundary in non-bloom times (Wetzel 2010). Nereites missourensis is interpreted as a eurybathic form mainly registered in flysch deposits (Uchman et al. 2005). It has also been reported from the distal delta-front environment in relation to opportunistic colonization during intervals of low-energy (Carmona et al. 2009).

Ichnogenus: Ophiomorpha Lundgren 1891

Ichnospecies: Ophiomorpha nodosa Lundgren 1891 (figure 7c)

Materials: Five specimens each collected from Gelmon (MIMOph - 1 to 5), Gopibung (MIMOph - 6 to 10), Leimatak (MIMOph - 11 to 15) and Thong jaorok (MIMOph - 16 to 20) with many more field occurrences in the above places. The Gelmon and Gopibung specimens are found in silty shale and fine sandstone; Leimatak speimens are observed in fine-to-medium and thin-bedded to massive sandstone; Thongjaorok specimens are associated with silty shale-fine sandstone intercalation as well as in fine-to-medium sandstone which are thinly-bedded to massive.

Description: Horizontal and vertical, mainly straight tubes, occasionally branched burrow systems showing Y-shaped branching (Rajkumar et al. 2008). Individual cylindrical tubes are $10-30 \mathrm{~mm}$ in diameter, with oval cross-sections, and around $100 \mathrm{~mm}$ long. Burrows have smooth interior and very distinct exterior surfaces; densely covered by muddy ovoid pellets $1-4 \mathrm{~mm}$ in diameter. The tubes are filled with fine and medium sand, similar to the host rock.

Remarks: Ophiomorpha tracemaker is difficult to access, being a possible combination of deposit and/ or suspension feeding; in modern environments, Ophiomorpha isp. were produced by callianassid crustaceans (Uchman and Gaździcki 2006). Pellets are usually interpreted as supporting the structure during and after burrow construction (Bromley and Ekdale 1998). The ichnogenus is found to occur in a wide environmental range from shallow-water deposits represented mainly by $O$. nodosa to deepsea environments represented mainly by $O$. rudis (Tchoumatchenco and Uchman 2001); most typical of the relatively high-energy, proximal, Skolithos ichnofacies (Pemberton et al. 2001).

Ichnogenus: Palaeophycus Hall 1847

Ichnospecies: Palaeophycus striatus Hall 1847 (figure 7d)

Materials: One specimen each collected from Gelmon (MIMPa - 1), Gopibung (MIMP - 2) and Thongjaorok (MIMPa - 3) with more field occurrences. The Gelmon and Gopibung specimens are associated with silty shales, and Thongjaorok specimen with fine sandstone.

Description: The specimens studied have lengths about 150-200 $\mathrm{mm}$ with burrow diameters ranging between 20 and $25 \mathrm{~mm}$. Burrow fill is structureless. Striae are $0.5-1 \mathrm{~mm}$ and nearly as long as the whole length of the specimens. Burrow collapse is absent.

Remarks: Palaeophycus is distinguished from Planolites by the presence of wall linings and by burrow-fill identical to the host rock in the former (Pemberton and Frey 1982) and from Macaronichnus by the active burrow-fill of the latter (Curran 1985). The ichnospecies is described as a eurybathic faciescrossing dwelling structure (domichnia) of suspension feeders or predators, such as polychaetes (Pemberton and Frey 1982). The predaceous glycerid polychaete, Glycera, has been taken as an excellent modern analog for the Palaeophycus organism. P. striatus is mainly registered in marine environments (Krapovickas et al. 2008).

Ichnogenus: Palaeophycus Hall 1847

Ichnospecies: Palaeophycus tubularis Hall 1847 (figure 7e)

Materials: Five, two and six specimens respectively observed at Gopibung, Keithelmanbi and Leimatak sections. They are all associated with shale and silty shale.

Description: Slight to prominently curved or even meandering (two meanders at maximum), thinly-lined horizontal and unbranched burrows. Surface walls 
are irregularly smooth and lack striations or annulations. Burrow diameters typically are about $10-15 \mathrm{~mm}$ and the length about $350-400 \mathrm{~mm}$. The burrow fill is identical to the host rock. Cross-cutting and interpenetration is seen between specimens.

Remarks: The specimens observed are thinly lined and are very much like $P$. tubularis; probably produced by worm-like creature living in watersaturated sediment produced in marine environments. They represent passive sedimentation within an open dwelling burrow constructed by predaceous or suspension feeding organisms, predominantly annelids (Pemberton and Frey 1982).

Ichnogenus: Parahaentzschelinia Chamberlain 1971 Ichnospecies: Parahaentzschelinia surlyki Chamberlain 1971 (figure 7f)

Materials: Four specimens observed in fine sandstone at Thongjaorok.

Description: Vertically bundled small tunnels radiating obliquely upward from a central, straight main tunnel and preserved in full relief. Diameter of the small tunnel is $\sim 3 \mathrm{~mm}$. Surface patterns are less than $60 \mathrm{~mm}$ across; central main tunnel is about $1.3 \mathrm{~mm}$ across.

Remarks: Parahaentzschelinia surlyki differs from the type species $P$. ardelia (Chamberlain 1971) in its characteristic irregular well-developed wall structure, its larger size and vertical main tunnel. The main structure seems to have developed as the trace maker repeatedly extended itself up and outward from a fixed point within the sediment in search for food and is classified as domichnion. The thick wall lining of $P$. surlyki may be related to substrate coherence, which was probably incohesive and loose at the time of burrowing.

Ichnogenus: Phycodes Hall 1852

Ichnospecies: Phycodes palmatus Hall 1852 (figure 8a)

Materials: Two specimens collected from Gelmon (MIMPhy - 1) from shale (MIMPhy - 2) and silty shale, with a few more field occurrences.

Description: The specimen from Gelmon locality consists of three unequal branches that were given off from a single point. The traces are oval in cross sections, which could be due to compaction. Length varies from 100-122 mm, with diameter of the branching tube about $15 \mathrm{~mm}$ at the apex and near the joints. Burrows filled by very fine-grained sand in a silty mudstone host.

Remarks: Phycodes is commonly present at the base of thin siltstone or silty sandstone beds within shales (Mángano et al. 2005). The tracemaker is mainly assigned to a sediment-feeding vermiform annelid, a pennatulacean, or an anthoptiloid sea pen. Phycodes palmatus is mainly related with shallow water environments, being characteristic trace fossil of the Cruziana ichnofacies, and less frequently found in deep-marine and non-marine conditions (Han and Pickerill 1994).

Ichnogenus: Protovirgularia Miller and Dyer 1878 Ichnospecies: Protovirgularia rugosa Miller and Dyer 1878 (figure 8b)

Materials: Two specimens collected (MIMPro -1 and 2) from fine sandstone and many more field occurrences at Leimatak section.

Description: The winding burrow is tubular in nature with burrow diameter varying from 5 to $10 \mathrm{~mm}$, aligned parallel to bedding plane. Generally the burrows are fairly sinuous. Successive pads of silty and fine sandy sediments 1-2 mm thick show characteristic imbricate structure. The specimens are comparable to the type species of Imbrichnus (Hallam 1970) in their sinuous course with imbricate structure. At sharp bends, the imbrications tend to splay out. Remarks: The originally proposed ichnogenus Imbrichnus (Hallam 1970), together with other ichnotaxa, were later synonymized within Protovirgularia by Seilacher and Seilacher (1994), on the basis of a similar behaviour. Protovirgularia rugosa has been related to a deposit feeding nucoloid bivalve (Seilacher and Seilacher 1994), probably Notonucula (Bradshaw 2010). The imbricate structures of the specimens indicate locomotive feeding-excreta of a tracemaker on sediment surface after turbidity current events (Gong 1999).

Ichnogenus: Rhizocorallium Zenker 1836

Ichnospecies: Rhizocorallium jenense Zenker 1836 (figure 8c)

Materials: Two specimens collected from Gopibung (MIMRh -1 and 2) in silty shale; a cluster (MIMRh - C) comprising of about 10 specimens in shale from Thongjaorok was collected.

Description: The Gopibung specimens are well preserved with protrusive sprieten. One of the tubes is about $13 \mathrm{~mm}$ in diameter $40 \mathrm{~mm}$ apart; short and about $110 \mathrm{~mm}$ long, which could be possibly due to fragmentation. The second specimen is about $40 \mathrm{~mm}$ apart with the tube diameter approximatey $6 \mathrm{~mm}$. It is slightly curved protrusive burrow with sprietens and tube having scratch marks. The Thongjaorok specimens are somewhat different in outlook as they are found as a cluster. Burrows are retrusive type and commonly oblique to the bedding plane. The marginal tube is about $6 \mathrm{~mm}$ wide. They are preserved in muddy sediments and the fills are fine sands.

Remarks: Rhizocorallium jenense occurs in greatly variable settings; usually related to unstable sedimentary environments, i.e., foreshore, high-energy regimes (Fürsich 1975). It is also related to more intermediate shoreface depths (Worsley and Mork 2001) and to transgressive surfaces, produced during 

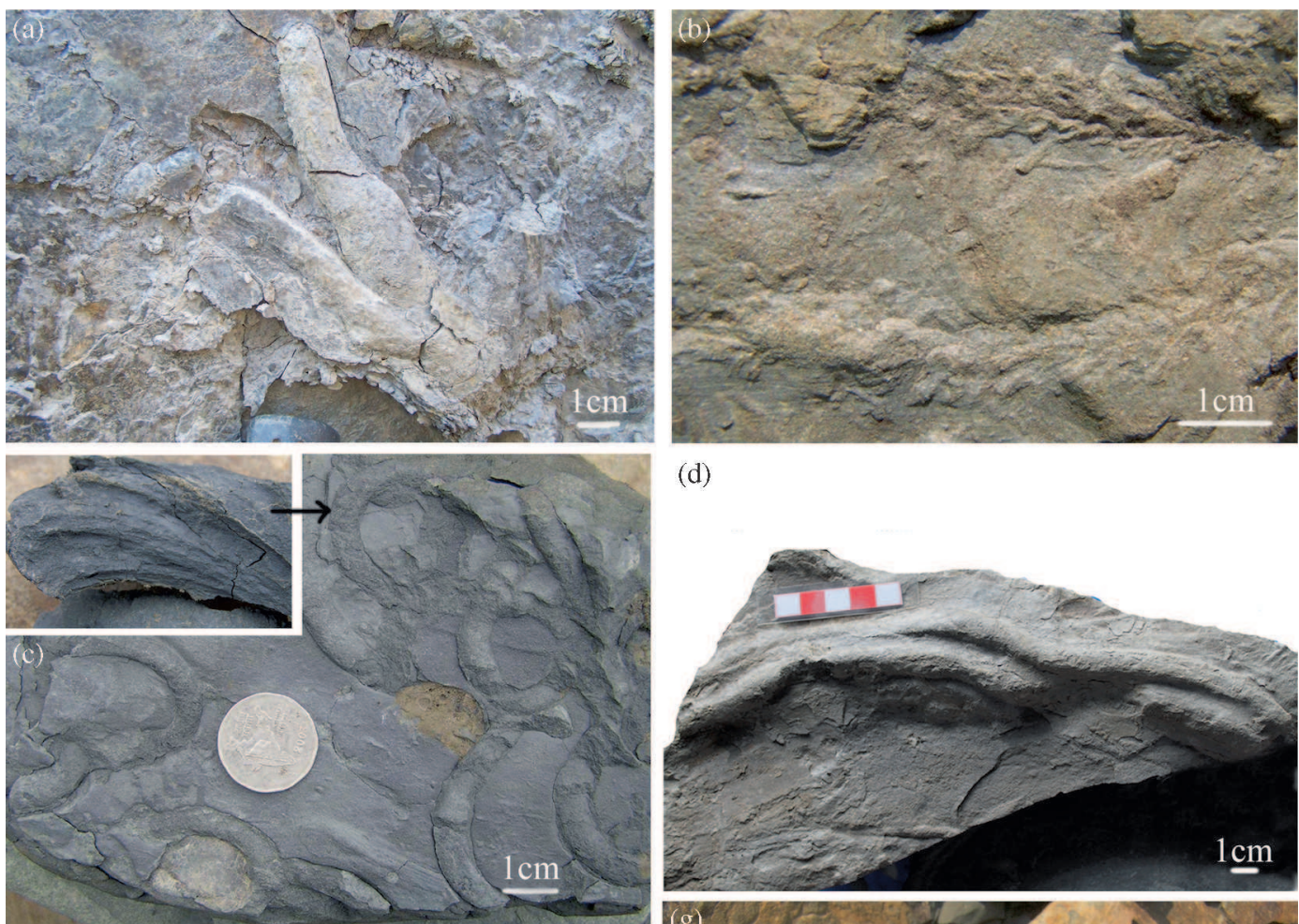

(d)
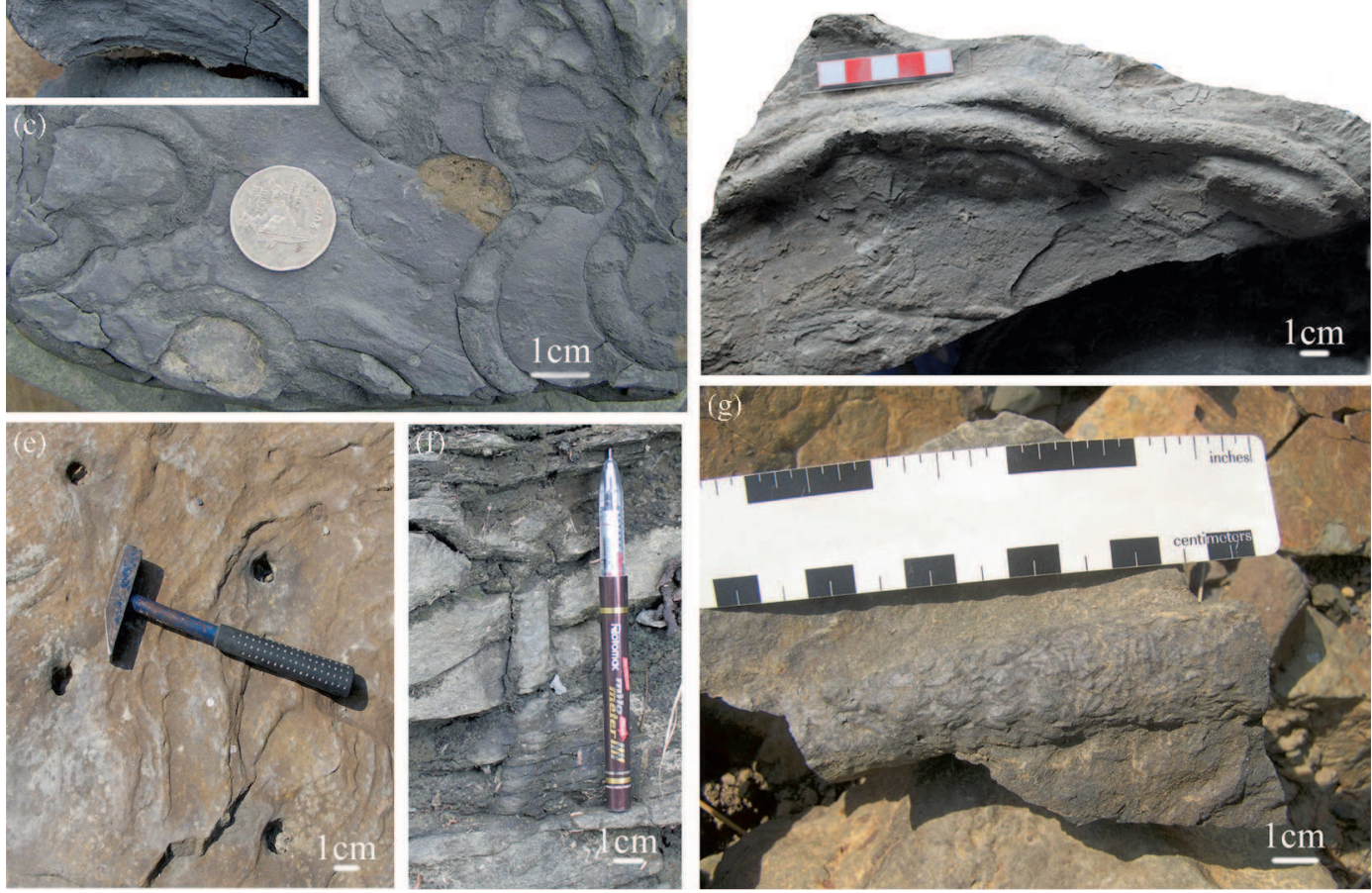

Figure 8. (a) Phycodes palmatus found in shale at Gelmon. (b) Protovirgularia rugosa found in fine sandstone, Leimatak. (c) Rhizocorallium jenense in shale, inset is a fragmented portion showing the sprietens, which can be seen clearly right below the portion indicated by arrow. The specimens are from Thongjaorok. (d) Scolicia plana, associated with massive fine sandstone, Gelmon. (e) Skolithos linearis seen on bedding plane of massive fine sandstone, Thongjaorok. (f) Skolithos linearis in vertical section from Leimatak in thin-bedded fine sandstone. (g) Spongeliomorpha suevica with silty shale host, Keithelmanbi.

a period of non-deposition, before and at the beginning of the subsequent deposition (Uchman et al. 2000; Rodriguez Tovar et al. 2007). The studied specimens are very much likely associated with trangressive surface as the burrow systems were usually formed when crustaceans colonized an exhumed firmground after sea level fall and before sandy shoreface sediments were introduced.

Ichnogenus: Scolicia de Quatrefages 1849

Ichnospecies: Scolicia planna Książkiewicz 1970 (figure 8d)

Materials: Three and two specimens collected from Gelmon (MIMSco -1 to 3 ) and Leimatak
(MIMSco - 1 to 3 ) sections respectively. They are all associated with massive fine sandstone.

Description: Meandering, smooth, bilobate hypichnial ridge, about $25 \mathrm{~mm}$ wide and up to $5 \mathrm{~mm}$ high, divided by a semicircular axial furrow about $10 \mathrm{~mm}$ wide; preserved as semi-relief in fine-grained sandstone.

Remarks: Uchman (1995) reviewed this ichnogenus and included Taphrhelminthopsis, Laminites, Subphyllochorda and Taphrhelminthoida as toponomic variants of Scolicia; the producers are irregular echinoids of the Spatangus group, with two drainage tufts that produce the drain channels. The medial string is considered faecal in origin, 
because of its darkness compared to the surrounding sediments, indicating that the tracemaker was actively feeding as it passed through the sediment. Holothurians or large polychaetes are considered as the most likely tracemakers. The deposit-feeding behaviour of the tracemaker makes Scolicia an elite ichnofabric forming trace fossil (sensu Ekdale and Bromley 1991).

Ichnogenus: Skolithos Haldeman 1840

Ichnospecies: Skolithos linearis Haldeman 1840 (figure 8e and f)

Materials: Many field observations at Gelmon, Gopibung, Leimatak sections and Thongjaorok. Two specimens (MIMSk-1 and 2) collected from Leimatak. The specimens are associated with varied sediments like shale, silty shale, thin-bedded to massive fine sandstone.

Description: The specimens are predominantly vertical to sub-vertical, straight, cylindrical showing more or less uniform diameter from 3-20 mm. Length between 40 and $270 \mathrm{~mm}$, but frequently about $120 \mathrm{~mm}$. Filled with structureless, medium sand, similar to the host rock. More or less isolated burrows occur, predominantly as small, ring-like projections on top of bedding planes.

Remarks: Archetypal Skolithos ichnofacies are related to relatively high energy environments, shallow water conditions, in nearshore to marginal marine settings (cf. Fillion and Pickerill 1990). Marine Skolithos is mainly interpreted as a domichnion structure made by polychaetes like Arenicola, Onuphis, Sabellaria and phoroids or annelids (Schlirf and Uchman 2005). Rajkumar et al. (2008) reported Skolithos linearis from the Disang-Barail transition sediments of Manipur indicating shallow-marine environment, with occasional high-energy conditions.

Ichnogenus: Spongeliomorpha Saporta 1887

Ichnospecies: Spongeliomorpha suevica Saporta 1887 (figure 8g)

Materials: Four fragmented specimens observed near Keithelmanbi and one relatively large network at Gelmon. The Keithelmanbi specimens are associated with silty shale and the Gelmon specimens with fine sandstone.

Description: Burrows with ornaments of short ridges on the surface. Burrow diameter is $25 \mathrm{~mm}$ with massive fills composed of sandy sediment; preserved as hypichnion in silty shale and fine sandstone.

Remarks: Specimens from Keithelmanbi are fragmentary; however, the Gelmon specimens are more complete though the surfaces are partially eroded. The short scratches are oriented parallel to incline with the axis of the burrow. The specimen differs from Spongeliomorpha sicula (D'Alessandro and Bromley 1995) in the absence of longitudinally extended ridges and ovoid chambers; from $S$. chevronensis by the absence of regularly distributed oblique ridges, and from S. sinuostriata by lack of long and sinuous scratch ornaments (Muñiz and Mayoral 2001). The trace makers may be either shrimps or stomatopods (Patel and Desai 2001). Spongeliomorpha isp. is characteristic of high energy shallow water environment. The burrow systems were formed when crustaceans colonized an exhumed firmground after sea level fall and before sandy shoreface sediments were introduced (de Gibert and Ekdale 2010).

Ichnogenus: Taphrhelminthopsis Sacco 1888

Ichnospecies: Taphrhelminthopsis auricularis 1888 (figure 9a)

Materials: Twelve and seven specimens studied at Leimatak and Gelmon sections, respectively with more field occurrences. The specimens are found in thin-bedded fine sandstone.

Description: The width of the specimen is about $3 \mathrm{~mm}$ and the ridges $2 \mathrm{~mm}$ high. The lateral ridges slope gently toward the trough and are generally smooth. The associated sediments are fine-grained sandstone. Most of the traces are casts.

Remarks: The specimens may be assigned to Taphrhelminthopsis auricularis (Sacco 1888; Książkiewicz 1977). The traces were formed either as surface locomotion trails by animals crawling on the sea bottom or are excavated burrows which were formed when current removed the soft muddy filling of the full burrow and filled the excavated furrow with sand (Seilacher 1962). Profuse occurrences of Taphrhelminthopsis are mainly connected with a well-oxygenated bottom. More distal and frequent sedimentation of turbidites could positively influence the preservational potential of the surface forms but the oxygen condition was the main controlling factor for the occurrence of the ichnofauna.

Ichnogenus: Teichichnus Seilacher 1955

Ichnospecies: Teichichnus isp. Seilacher 1955 (figure 9b)

Materials: Five specimens observed at Gelmon in silty shale.

Description: Horizontal burrows with retrusive spreiten stacked vertical to bedding; preserved in full relief; burrow diameter $10-15 \mathrm{~mm}$ and depth up to $50 \mathrm{~mm}$.

Remarks: The studied specimens have close affinity with Teichichnus rectus. Seilacher (1955) compared these forms to the modern structures made by the recent polychaete Nereis diversicolor. Teichichnus isp. is a wall-like, internally laminated trace produced by the vertical migration of horizontal cylindrical burrows formed by deposit-feeders (Häntzschel 1975); generally related to burrows of annelids or arthropods and can be classified as a fodinichnion (Vossler and Pemberton 1989). Structures of this 

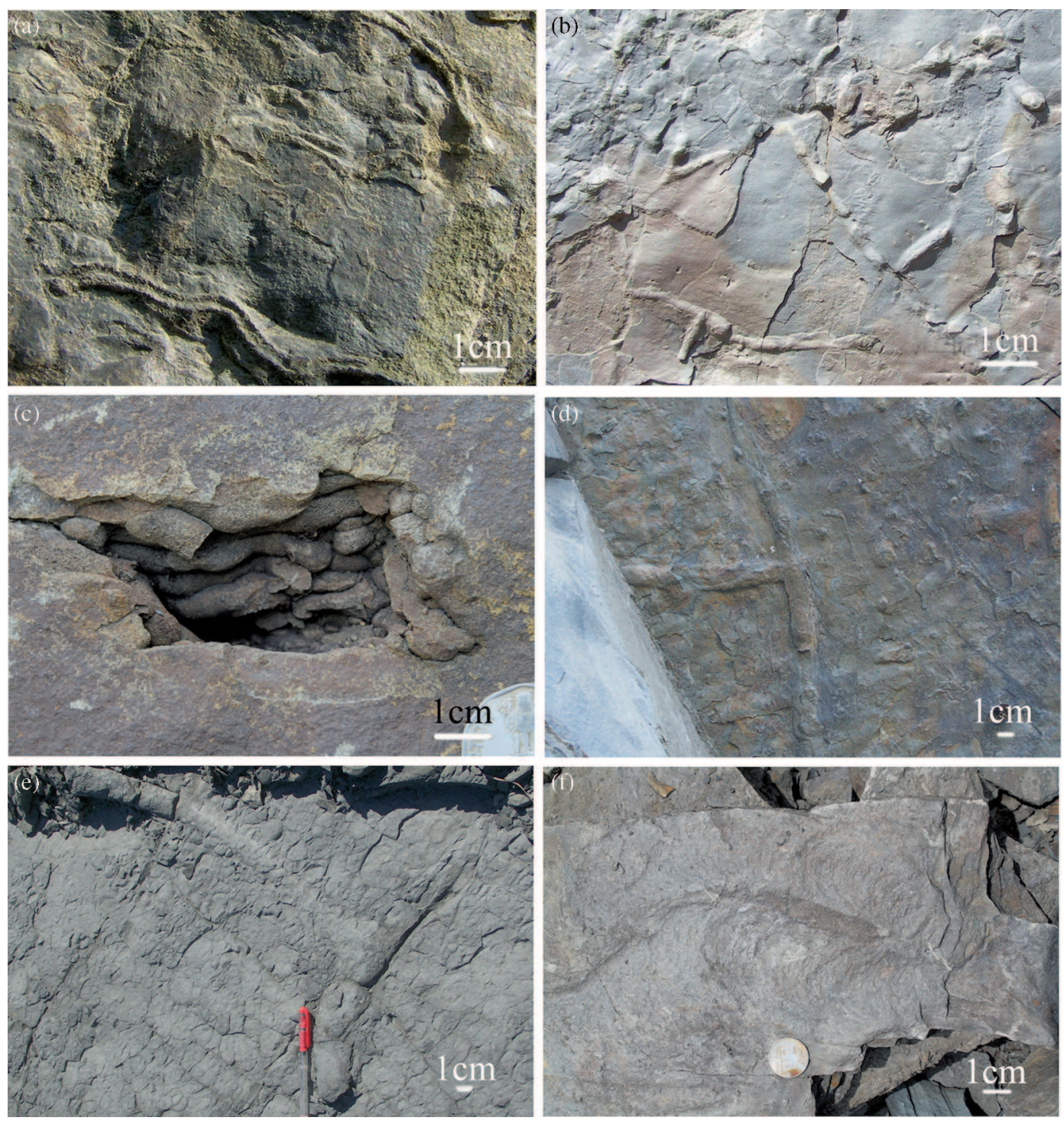

Figure 9. (a) Taphrhelminthopsis auricularis in fine sandstone, Leimatak. (b) Teichichnus isp. in silty shale, Gelmon. (c) Teredolites longissimus in massive fine sandstone, Tentha. (d) Thalassinoides horizontalis in thin-bedded fine sandstone, Gelmon. (e) Thalassinoides paradoxicus in silty shale, Atuyang. (f) Zoophycos isp. in thin-bedded fine sandstone, Gelmon.

type can be produced as a result of disturbance and redistribution of sediment by displacement of the burrow system, leaving a reworked filling, floor or spreite. Teichichnus isp. is a chronologically long ranging ichnogenus which apparently represents the mining pattern of an intrastratal deposit feeder (Häntzschel 1975). The trace represents a mixed Skolithos-Cruziana ichnofacies (McIlroy 2004).

Ichnogenus: Teredolites Leymerie 1842

Ichnospecies: Teredolites longissimus Kelly and Bromley 1984 (figure 9c)

Materials: Four well preserved specimens observed in massive fine sandstone at Tentha Hill $\left(24^{\circ} 34^{\prime} 12.34^{\prime \prime} \mathrm{N}\right.$ and $093^{\circ} 58^{\prime} 56.43^{\prime \prime} \mathrm{E} ; 788 \mathrm{~m}$ ).

Description: Clusters of tubes with subcircular cross-sections, commonly sinuous to contort. Diameter of the tubes is about 6-8 $\mathrm{mm}$; surface of which resemble carbonised woody substrate.

Remarks: Dwelling and feeding traces made by wood-boring bivalves or suspension feeders such as the modern shipworm, Teredo. They range in age from Cretaceous to Recent. In fact, some horizons are pretty much taken over by Teredolites, indicative of considerable amount of woody (or xylic) substrates. Bromley et al. (1984) recognized that this was a fundamentally different condition from the traditional soft-firm-hardground spectrum, and helpfully named as 'woodgrounds' (i.e., coal, peat, or wood) submerged in open marine waters that uniquely identifies the occurrences of woodgrounds in the rock record; Teredolites longissimus are found in flood-dominated tidal facies within a delta front shoreface (cf. Gingras et al. 2004); marginal/shallow marine (Tewari et al. 1998). 
Ichnogenus: Thalassinoides Myrow 1995

Ichnospecies: Thalassinoides horizontalis Myrow 1995 (figure 9d)

Material: Five specimens were collected (MIMThh -1 to 5) with many field occurrences at Gelmon. The host sediments are thin-bedded fine sandstone.

Description: Smooth-walled, unlined, horizontal branched burrows. The bedding-parallel boxwork or polygonal frameworks contain both $\mathrm{Y}$ and $\mathrm{T}$ junctions. Burrows lack swelling at junctions. Burrow diameters are constant within each specimen at $7 \mathrm{~mm}$ and $10 \mathrm{~mm}$.

Remarks: Thalassinoides isp. is generally interpreted as a fodinichnial (Bromley 1996) or domichnial structure, passively filled, mainly attributed to crustaceans (Frey et al. 1984). They are faciescrossing form, being related to a variety of marine environments, from tidal flat and shoreline to offshore outer shelf and deep-sea (Myrow 1995), but most typically registered in shallow-marine environments. Usually related to oxygenated, soft and fairly cohesive substrates (Bromley 1996); occur in firmground and in the first stage of hardground development (Myrow 1995); related with the Glossifungites ichnofacies (Savrda et al. 2001). Compared to several ichnospecies of Thalassinoides isp., recognized as valid and useful (cf. Ekdale and Bromley 2003), the studied specimens have been assigned to $T$. horizontalis Myrow based on the horizontal orientation and absence of vertically oriented offshoots (cf. Blissett and Pickerill 2004).

Ichnogenus: Thalassinoides Woodward 1830

Ichnospecies: Thalassinoides paradoxicus Woodward 1830 (figure 9e)

Material: Twenty specimens studied with many more field occurrences at Gelmon, Gopibung, Leimatak sections and Thongjaorok. Only three specimens (MIMThp -1 to 3) collected from Thongjaorok. They are usually associated with shale, silty shale and fine sandstone.

Description: Smooth-walled, irregularly branched; mainly Y-shaped. Burrow diameter varies from 3 to $50 \mathrm{~mm}$ (average of about $20 \mathrm{~mm}$ ) (Rajkumar 2005; Rajkumar et al. 2008), with intermittent enlargements in the bifurcation points. Size of burrow fills different from that of the host material.

Remarks: The high irregularity of size and geometry of burrow system allow us the assignation of the studied specimens to Thalassinoides paradoxicus Woodward. Typically found occurring in shallowmarine environments. Usually related to oxygenated, soft and fairly cohesive substrates (Bromley 1996); occur in firmground and in the first stage of hardground development (Myrow 1995); related with the Glossifungites ichnofacies (Savrda et al. 2001).
Ichnogenus: Zoophycos Massalango 1855

Ichnospecies: Zoophycos isp. Massalango 1855 (figure 9f)

Material: Two moderately well preserved (but fractured) specimens collected from thin-bedded fine sandstone, Gelmon (MMZ - 1 and 2).

Description: One of the specimens shows two lobes with sprieten directing in different directions. The morphology of the body is nearly flat. Lobes rimmed by moderately well-developed marginal tube. Sprietens are curved with primary laminae. Entry tube from which the lobes may have arisen is not visible as the specimen is fragmented. However, a faint spot that likely represent the cone axis is oriented almost transverse to the bedding. The loop is $60-130 \mathrm{~mm}$ across and spiral is about $10 \mathrm{~mm}$ high. Length of the specimen is about $250 \mathrm{~mm}$.

Remarks: The specimens are probably horizontal sections of helical lobes of Zoophycos. The form can be compared to Zoophycos insignus on the basis of lobed appearance (cf. Patel et al. 2009). It is a complex fodichnial structure. Palaeozoic occurrences are registered in environments going from the nearshore to slope and deep basin (Bottjer et al. 1988). Buatois et al. (2005) reported Zoophycos as a common component of Carboniferous esturine deposits. The tracemaker tolerated several bathymetrical settings, being an element of Cruziana, Zoophycos and Nereites ichnofacies; quiet water, stressed environments seem to be the preferential conditions under which Zoophycos tracemaker established (Pemberton et al. 2001); occurrence in shallow depositional setting for the Cenozoic (cf. Pervesler and Uchman 2004). The palaeoenvironment for the Zoophycos isp. bearing horizon at Gelmon locality may be below storm wave base, based on the absence of any tempestites in the horizon.

\section{Palaeonvironmental implications}

Analysis of the moderately abundant and diverse trace fossils and associated sedimentary structures of the Laisong (flysch) sediments offer significant information to interpret palaeoenvironment and sea-level dynamics during the Late Eocene-Early Oligocene.

Ichnogenera such as Bergaueria hemispherica, Furculosus isp., Gyrochorte comosa, Ophiomorpha nodosa, Skolithos linearis and Teredolites longissimus usually indicate shallow marine setting with high-energy conditions typical of the Skolithos ichnofacies. Skolithos ichnofacies and their association with herringbone structures distinctive of tidal flats (figure 10a), pot cast (figure 10b), cross-beds, rain prints (figure 10c), hummocky cross beds (figure 10d), 

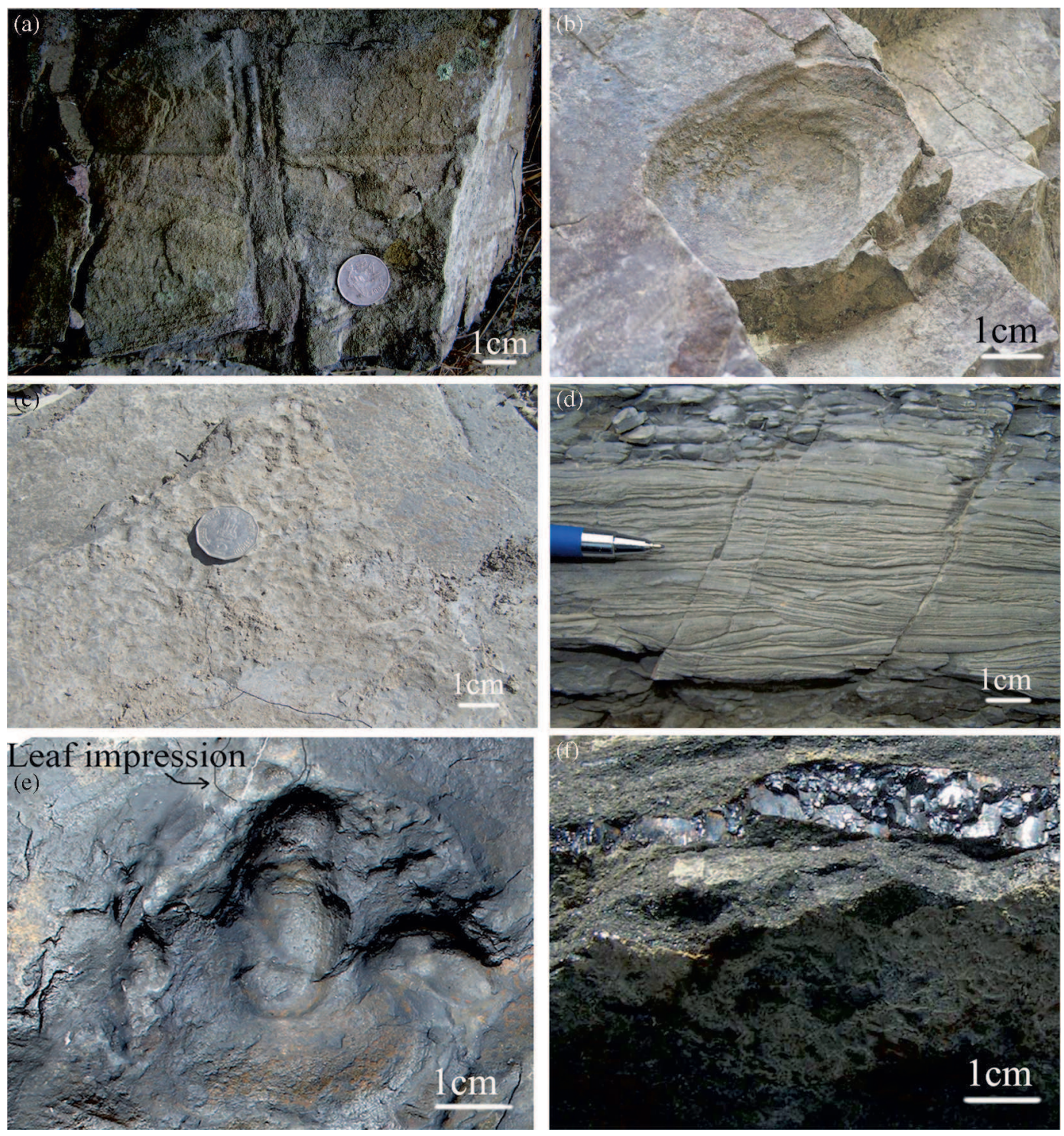

Figure 10. (a) Herringbone structures in medium sandstone, Thongjaorok. The structure is cut vertically by Ophiomorpha nodosa. (b) Pot cast in thin-bedded fine sandstone, Thongjaorok. (c) Rain prints in thin-bedded fine sandstone, Gelmon. (d) Hummocky cross-stratifications in silty shale, Thongjaorok. (e) Perissodactyl track with leaf impression preserved in silty shale bed about $3 \mathrm{~cm}$ thick (from Rajkumar and Klein 2014). (f) Coal lenses in thin-bedded medium sandstone, Thongjaorok.

gutter casts, etc., are characteristic of a high-energy environment in the foreshore and shoreface zones including beaches, bars and spits (cf. Seilacher 1967; Howard 1975). The presence of perissodactyl footprints (figure 10e) (Rajkumar and Klein 2014) and occurrence of coal layer about $2 \mathrm{~cm}$ thick at Thongjaorok locality (figure 10f) further suggest a very shallow marginal marine and deltaic settings, respectively.

The presence of Aulichnites parkerensis, Chondrites targionii, Helminthopsis tenuis, Palaeophycus striatus, Palaeophycus tubularis, Phycodes palmatus, and Thalassinoides paradoxicus, with a mixture of vertical and horizontal biogenic structures represent Cruziana ichnofacies in a typical beach-to-offshore profile characterised by occurrence below fairweather wave base but above the storm wave base
(Frey and Seilacher 1980); which is also characterized by sedimentary structures such as, rippled and trough-cross beddings, hummocky cross-stratifications, etc. The dominance of horizontal forms over the vertical forms suggests a reduced energy level and minimal abrupt changes in environmental parameters (i.e., temperature, salinity and sedimentation rates). Cruziana ichnofacies is also evocative of activities of mobile carnivores and deposit feeders exploiting relatively nutrient-rich, fine-grained sediments deposited in low-energy, offshore environment.

Desmograpton alternatum, Halopoa imbricata, Helminthoraphe flexuoxa, Nereites missouriensis, Palaeodictyon maximum, Palaeodictyon strozzi, Taphrhelminthopsis isp. usually occur in deep, quiet environments, mainly representing the Nereites ichnofacies in general. However, the co-existence 


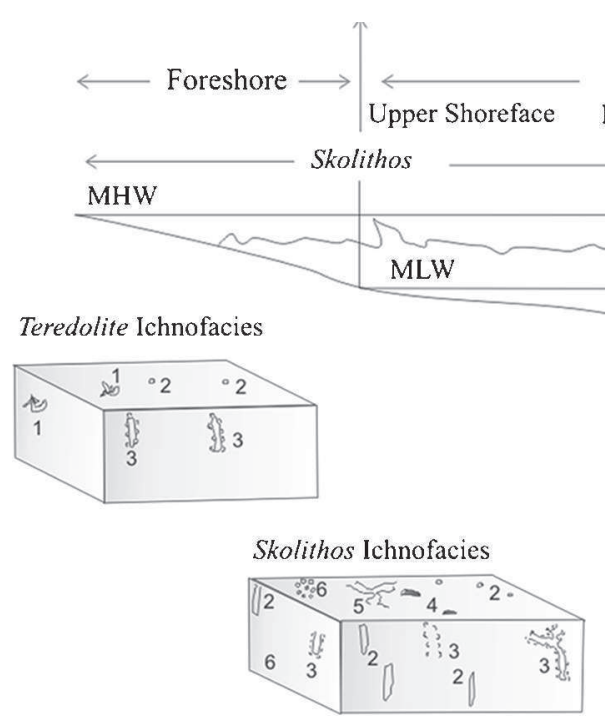

Ichnospecies Reference

1. Teredolite longissimus
2. Skolithos linearis
3. Ophiomorpha nodosa
4. Bergauria hemispherica
5. Thalassinoides isp.
6. Parahaentzschelinia surlyki
7. Furculosus isp.
8. Acanthoraphe isp.
9. Rhizocorallium jenense
10. Phycodes palmatus
11. Aulichnites parkerensis
12. Spongeliomorpha suevica
13. Palaeophycus isp.
14. Archaeonassa isp.
15. Protovirgularia rugosa
16. Gyrochorte comosa
17. Ancorichnus ancorichnus
Tranzitional zone

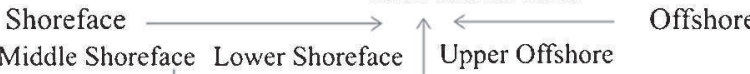

Lower Offshore $\longleftarrow$ Bathyal Zone $\longrightarrow \leftarrow$ Abyssal Zone $\rightarrow$ $\longrightarrow$ Proximal Cruziana $\longleftrightarrow$ Cruziana $\longleftrightarrow$ Distal Cruziana $\longrightarrow$ $\underbrace{2}$

Skolithos-Cruziana mixed Ichnofacies
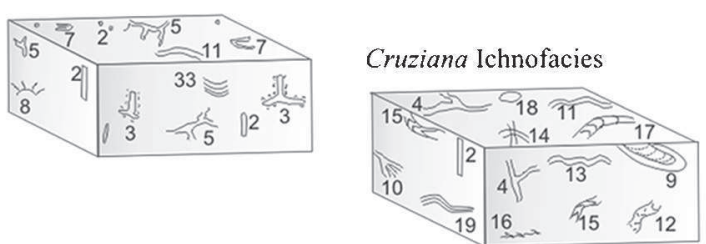

18. Circulichnus isp

9. Scolicia isp.

20. Zoophycos isp.

21. Gyrophyllite kwassizensis

22. Chondrites targionii

23. Gordia marina

24. Helminthoidichnites isp.

25. Helminthopsis tenuis

26. Nereites missourensis

27. Nereites missourensis
28. Pallerhaphe flexuoxa

28. Palaeodictyon isp.
29. Halopod interich

29. Halopoa imbricata

30. Megagrapton isp.

31. Desmograpton alternatum

32. Taphrehelminthopsis auricularis

33. Teichichmus isp.

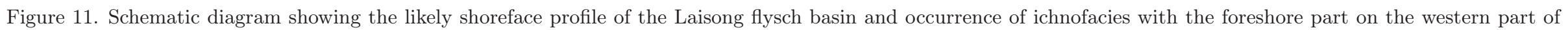
Myanmar continental landmass and the generalized onshore-offshore direction towards WNW. 
of Nereites missourensis with Thalassinoides paradoxicus in dark grey shale characterized by the presence of ripple marks and co-occurrence of Palaeodictyon maximum and Palaeodictyon strozzi with Thalassinoides horizontalis in thin-bedded fine sandstone imply the possibility of an otherwise (?localized) shallow marine depositional setting. Uchman (1995) observed the presence of Palaeodictyon isp. in shallow-water deposits though Palaeodictyon isp. is considered as a typical deep-water graphoglyptids in general.

The Zoophycos ichnofacies is represented by the presence of Zoophycos isp. in thin-bedded fine sandstones and may represent deposition below storm wave base, which is also supported by the absence of any tempestites in the horizon.

The occurrence of the Nereites ichnofacies and Zoophycos ichnofacies between sediment strata dominantly characterized by Skolithos ichnofacies and Cruziana ichnofacies suggest significant variations in the depositional setting, especially with respect to bathymetry and energy conditions. Taking into consideration the tectonic setting in the region during deposition of the Laisong sediment (cf. Soibam 1998, 2000), the occurrence of Nereites ichnofacies and Zoophycos ichnofacies may represent intermittently subsiding basin rather than the broad abyssal plain. Such a depositional setting may be explained by pulsatic stretching of the Laisong Basin. That is continual sedimentation caused shallowing of the basin. Accommodation space to the shallowed basin could only be provided by deepening of the basin due to crustal stretching, as part of the Indo-Myanmar Basin (Flysch basin) resulted from the stretching (passive rifting) of the western continental margin of the Myanmar landmass (Soibam et al. 2013); the mechanism on passive continental margin basin development and deposition of flysch sediments may be invoked from Gerhard (2000). Figure 11 represents the schematic diagram showing the likely shoreface profile and occurrence of ichnofacies of the Laisong flysch basin.

\section{Conclusions}

- The Laisong flysch successions of Manipur, northeast India, contain a relatively diverse trace fossils comprising of 36 ichnospecies belonging to 33 ichnogenera.

- The ichnospecies are classified into Teredolites ichnofacies, Skolithos ichnofacies, Cruziana ichnofacies, Zoophycos ichnofacies and Nereites ichnofacies.

- Presence of Teredolites ichnofacies suggests channel fill deposit in deltaic fan region.
- The occurrence of Skolithos ichnofacies and associated sedimentary structures point towards sublittoral marine setting with significant and complex wave activity.

- Cruziana ichnofacies implies offshore settting with relatively nutrient-rich, fine-grained sediments deposited in low-energy environments.

- Occurrence of Zoophycos ichnofacies and Nereites ichnofacies and association of massive and structureless beds, parallel laminations, load casts with characteristic squeezed and lineated downward protrusions that marked the base of turbidites indicate deep turbidite succession.

- The vertical distribution of diverse ichnospecies at different level of Laisong succession (figures 2 and 3) indicates fluctuation in the basin depth that is shallowing and deepening. Regression of the basin was eventually due to sediment accumulation and transgression related to pulsatic crustal stretching leading to deepening of the then western continental margin basin on the Myanmar Plate (Soibam et al. 2013) during the Late Eocene-Early Oligocene times.

\section{Acknowledgements}

This research paper is an outcome of the Project F. 41-1030/2012 (SR) supported by UGC, New Delhi, Government of India and Project SR/S4/ES441/2009(G), Department of Science and Technology/SERB New Delhi. Thanks are due to Alfred Uchman, Institute of Geological Sciences, Jagiellonian, Kraków and FJR-Tovar, Department of Stratigraphy and Palaeontology, University of Granada, two anonymous reviewers and last but not the least Prof. G V R Prasad, Associate Editor of JESS for their invaluable comments and constructive suggestions.

\section{References}

Acharyya S K, Mitra N D and Nandy D R 1986 Regional geology and tectonic settings of northeast India and adjoining regions; Geol. Surv. India Memoir 119 6-12.

Biswas A and Mukhopadhyay B P 2011 Signature of a paleogene submarine-fan from the Jenam Formation, Barail Group, Assam-Arakan orogen, northeastern India; J. Geol. Soc. India 78(6) 510-522.

Blissett D J and Pickerill R K 2004 Soft-sediment ichnotaxa from the Cenozoic White Limestone Group, Jamaica, West Indies; Scripta Geologica 127 341-378.

Bottjer D J, Droser M L and Jablonski D 1988 Palaeoenvironmental trends in history of trace fossils; Nature $\mathbf{3 3 3}$ 252-255.

Bradshaw M A 2010 Devonian trace fossils of the Horlick Formation, Ohio Range, Antarctica: Systematic description and palaeoenvironmental interpretation; Ichnos $\mathbf{1 7}$ 58-114. 
Bromley R G 1996 Trace Fossils: Biology, Taphonomy and Applications; Chapman and Hall, London, 361p.

Bromley R G and Ekdale A A 1998 Ophiomorpha irregulare (trace fossil): Redescription from the Cretaceous of the Book cliffs and Wasatch plateau, Utah; J. Palaeontol. 72 773-778.

Bromley R G, Pemberton S G and Rahmani R A 1984 A Cretaceous woodground: The Teredolites ichnofacies; J. Paleontol. 58 488-498.

Brongniart A T 1828 Histoire des Végétaux Fossiles ou Recherches Botaniques et Géologiques sur les Végétaux Renfermés dans les Diverses Couches du Globe, 1. G. Dufour and E. d'Ocagne, Paris, pp. 1-136.

Buatois L A and Mángano M G 1993 Trace fossils from a Carboniferous turbidite lake: Implications for the recognition of additional non-marine ichnofacies; Ichnos $\mathbf{2}$ $237-258$.

Buatois L A and Mángano M G 2002 Trace fossils from Carboniferous floodplain deposits in western Argentina: Implications for ichnofacies models of continental environments; Palaeogeogr. Palaeoclimatol. Palaeoecol. 183 71-86.

Buatois L A and Mángano M G 2003 Sedimentary facies and depositional evolution of the Upper Cambrian to Lower Ordovician Santa Rosita Formation in northwest Argentina; J. South Am. Earth Sci. 16 343-363.

Buatois L A, Mángano M G, Maples C G and Lanier W P 1998 Ichnology of an Upper Carboniferous fluvio-estuarine palaeovalley: The tonganoxie sandstone, Buildex Quarry, eastern Kansas, USA; J. Palaeontol. 72 152-180.

Buatois L A, Gingras M K, MacEachern J, Mángano M G, Zonneveld J-P, Pemberton S G, Netto R G and Martin A 2005 Colonization of brakish-water systems through time: Evidence from the trace-fossils record; Palaios $\mathbf{2 0}$ 321-347.

Carmona N B, Buatois L A, Ponce J J and Mángano M G 2009 Ichnology and sedimentology of a tide-influenced delta, Lower Miocene Chenque Formation, Patagonia, Argentina: Trace-fossil distribution and response to environmental stresses; Palaeogeogr. Palaeoclimatol. Palaeoecol. 273 75-86.

Chakraborty A, Hasiotis S T, Gosh B and Bhattacharya H N 2013 Fluvial trace fossils in the Middle Siwalik (Sarmatian-Pontian) of Darjeeling Himalayas, India; J. Earth Syst. Sci. 122(4) 1023-1033.

Chamberlain C K 1971 Morphology and ethology of trace fossils from the Ouachita Mountains, southern Oklahoma; J. Paleontol. 45 212-246.

Chen Z Q, Ton J and Frasier M L 2011 Trace fossil evidence for restoration of marine ecosystems following the endPermian mass extinction in the Lower Yangtze region, South China; Palaeogeogr. Palaeoclimatol. Palaeoecol. 299 449-474.

Crimes T P, Legg I, Marcos A and Arboleya M 1977 ?Late Precambrian-Lower Cambrian trace fossils from Spain; In: Trace fossils 2 (eds) Crimes T P and Harper J, Geol. J. Spec. Issue 9 91-138.

Curran H A 1985 The trace fossil assemblage of Cretaceous nearshore environment: Englishtown Formation of Delaware, USA; In: Biogenic structures: Their use in interpreting depositional environments (ed.) Curran H A, Soc. Econ. Palaeontol. Mineral., Spec. Publ. 35 261-276.

D'Alessandro A 1980 Prime osservacioni sulla ichnofauna miocenica della "Formazione di Gorgolione" (Castelmezzano, Potenza); Riv. Ital. Paleont. Strat. 86 357-398.

D'Alessandro A and Bromley R G 1995 A new ichnospecies of Spongeliomorpha from the Pleistocene of Sicily; J. Paleontol. 69 393-398.
Dasgupta A B and Biswas A K 2000 Geology of Assam; Geology Society of India, 169p.

de Gibert J M and Benner J S 2002 The trace fossil Gyrochorte: Ethology and paleoecology; Revista Española de Paleontología 17 1-12.

de Gibert J M and Ekdale A A 2010 Paleobiology of the Crustacean trace fossil Spongeliomorpha iberica in the Miocene of southeastern Spain; Acta Palaeontologica Polonica 55(4) 733-740.

De Quatrefages 1849 Note sur la Scolicia prisca (A De Q) annelid fossile de la Craie; Annales des Sciences Naturelles, 3 série Zoologie 12 265-266.

Demircan H and Toker V 2004 Cingoz Formasyonu doğu yelpaze iz fosilleri (KB Adana) [Trace fossils of the eastern fan in Cingoz Formation (NW Adana)]; Maden Tetkik Arama Enstitüsü (MTA) Dergisi 129 69-87 (in Turkish with English abstract).

Desai B G and Saklani R D 2014 Ichnofabric analysis of the Tithonian shallow marine sediments (Bhadasar Formation) Jaisalmer Basin, India; J. Earth Syst. Sci. 123(6) 1413-1431.

Eichwald E 1868 Lethaea Rossica ou Paleontologie de la Russie; E Schweizerbart (Stuttgart), Vol. 1, 1657p.

Ekdale A A and Bromley R G 1991 Analysis of composite ichnofabrics: An example in uppermost Cretaceous chalk of Denmark; Palaios 6 232-249.

Ekdale A A and Bromley R G 2003 Paleoethologic interpretation of complex Thalassinoides in shallow-marine limestones, Lower Ordovician, southern Sweden; Palaeogeogr. Palaeoclimatol. Palaeoecol. 192 221-227.

Emmons E 1844 The Taconic System Based on Observations in New York, Massachusetts, Maine, Vermont, and Rhode-Island 63.

Evans P 1932 Explanatory notes to accompany a table showing the Tertiary successions in Assam; Trans. Mining and Geological Institute India 27 155-260.

Fenton C L and Fenton M A 1937 Burrows and trails from Pennsylvanian rocks of Texas: Midland; Naturalist 18 1079-1084.

Fillion D and Pickerill R K 1984 Systematic ichnology of the Middle Ordovician Trenton Group, St Lawrence Lowland, eastern Canada; Maritime Sediments and Atlantic Geology 20 1-41.

Fillion D and Pickerill R K 1990 Ichnology of the Upper Cambrian? to Lower Ordovician Bell Island and Waban groups of eastern Newfoundland, Canada; Palaeontographica Canadian 7 1-119.

Fitch A 1850 A historical, topographical and agricultural survey of the county of Washington. Part 2-5; Trans. New York Agr. Soc. 9 753-944.

Frey R W and Howard J D 1990 Trace fossils and depositional sequences in a clastic shelf setting, Upper Cretaceous of Utah; J. Palaeontol. 64 803-820.

Frey R W and Pemberton S G 1984 Trace Fossil Facies Models; In: Facies Models (ed.) Walker R G, 2nd edn (Kitchener, Ontario: Ainsworth Press Limited), pp. 189-207.

Frey R W and Seilacher A 1980 Uniformity in marine invertebrate ichnology; Lethaia 23 183-207.

Frey R W, Curran H A and Pemberton S G 1984 Trace making activities of crabs and their environmental significance: The ichnogenus Psilonichnus; J. Palaeontol. 58 $333-350$.

Fu S 1991 Funktion, Verhalten und Einteilung fucoider und lophocteniider Lebenspuren. Courier Forschungsinstitut Senckenberg; Senckenbergischen Naturforschende Gesellschaft, Frankfurt, pp. 1-79.

Fuchs T 1895 Studien über Fucoiden und Hieroglyphen. Denkschr Akad. Wiss. Wien, Math; Naturwiss Kl. 62 369-448. 
Fürsich F T 1975 Trace fossils as environmental indicators in the Corallian of England and Normandy; Lethaia 8 151-172.

Fürsich F T, Wilmsen M and Seyed-Emami K 2006 Ichnology of Lower Jurassic beach deposits in the Shemshak Formation at Shahmirzad, southeastern Alborz Mountains, Iran; Facies 52 599-610.

Gerhard E 2000 Sedimentary Basins Evolution, Facies and Sediment Budget; Springer-Verlag, 2nd edn, 792p.

Ghare M A and Kulkarni K G 1986 Jurassic ichnofauna of Kutch-II Wagad region; Biovigyanam 12 44-62.

Gingras M K, MacEachern J A and Pickerill R K 2004 Modern perspectives on the Teredolites ichnofacies: Observations from Willapa Bay, Washington; Palaios 19(1) 79-88.

Gloker F E 1841 Uber die kalkfuhrende Sandsteinformation auf beiden Seiten der mittleren March, in der Gegend zwischen Kwassitz und Kremsier: Nova Acta Acad. Caes. Leop.- Carol. German; Natur. Curios. 19(2) 309-334.

Gong Y 1999 Flysch trace fossil from Hercynian and Indosinian Orogenic Belts of northwestern China and their palaeoenvironmental significance; Acta Geologica Sinica 73(4) 384-394.

Guleria J S, Rajkumar H S, Mehrotra R C, Soibam I and Rajkumar K 2005 Palaeogene plant fossils of Manipur and their palaeoecological significance; Palaeobotanist 54 61-77.

Haldeman S S 1840 Supplement to number one of a "monograph of the Limniades, or fresh water univalves shells of the North America", containing descriptions of apparently new animals in different classes, and the names and characters of the subgenera in Paludina and Anculosa; Private Publication, 3p.

Hall J 1847 Palaeontology of New York, State of New York (Albany, NY), Vol. 1, 338p.

Hall J 1852; Ibidem 2362.

Hallam A 1970 Gyrochorte and other trace fossils in the Forest Marble (Bathonian) of Dorset, England; In: Trace Fossils (eds) Crimes T P and Harper J C, Liverpool, pp. 189-200.

Han Y and Pickerill R K 1994 Phycodes templus isp. nov. from the Lower Devonian of northwestern New Brunswick, eastern Canada; Atlantic Geology 30 37-46.

Häntzschel W 1962 Treatise on Invertebrate Paleontology; In: Part W, Miscellania (ed.) Moore R C, Geol. Soc. Amer. and Univ. Kansas Press, W177-W222.

Häntzschel W 1970 Star like trace fossils; In: Trace Fossils (eds) Crimes T P and Harper J C (Liverpool: Seel House Press), Geol. J., Spec. Issue 3 201-214.

Häntzschel W 1975 Trace fossils and problematica; In: Treatise on Invertebrate Palaeontology, Part W, Miscellanea, Suppl. (ed.) Teichert C, The Geol. Soc. America and Kansas.

Heer O 1865 Die Urwelt der Schweiz, Züruch (Friedrich Schultze), 622p, 11pls.

Heinberg C 1973 The internal structures of the trace fossils Gyrochorte and Curvolithus; Lethaia Oslo 6(3) 227-238.

Heinberg C 1974 A dynamic model for a meniscate filled tunnel (Ancorichnus n. ichnogen) from the Jurassic Pecten sandstone of Milne Land, east Greenland; Grønlands Geol. Undersøg. Rapp. 62 1-20.

Heinberg C and Birkelund T 1984 Trace fossil assemblages and basin evolution of the Vardekøft Formation (Middle Jurassic, Central East Greenland); J. Palaeontol. 58 362-397.

Hofmann H J and Patel I M 1989 Trace fossils from the type 'Etchemian Series' (Lower Cambrian Ratcliffe Brook Formation), Saint John area, New Brunswick, Canada; Geol. Mag. 126 139-157.

Honeycutt C E and Plotnick R E 2005 Mathematical analysis of Paleodictyon: A graph theory approach; Lethaia $\mathbf{3 8}$ 345-350.
Howard J D 1975 The sedimentological significance of trace fossils; In: The study of trace fossils (ed.) Frey R W, Springer-Verlag, New York, pp. 131-146.

Joseph J K, Patel S J and Bhatt N J 2012 Trace fossil assemblages in mixed siliciclastic-carbonate sediments of the Kaladongar Formation (Middle Jurassic), Patcham Island, Kachchh Western India; J. Geol. Soc. India 80 189-214.

Kelly S R A and Bromley R G 1984 Ichnological nomenclature of clavate borings; Palaeontology 27 793-807.

Kim J Y, Kim K and Pickerill R K 2002 Cretaceous non-marine trace fossils from the Hasandong and Jinju formations of the Namhae Area, Kyongsangnamdo, Southeast Korea; Ichnos 9 41-60.

Kim J Y, Keighley D G, Pickerill R K, Hwang W and Kim K S 2005 Trace fossils from marginal lacustrine deposits of the Cretaceous Jinju Formation, southern coast of Korea; Palaeogeogr. Palaeoclimatol. Palaeoecol. 218 105-124.

Krapovickas V, Mángano M G, Mancuso A, Marsicano C A and Volkheimer W 2008 Ichnofaunas triásicas en abanicos aluviales distales: Evidencias de la Formación Cerro Puntudo, Cuenca Cuyana, Argentina; Ameghiniana 45 463-472.

Książkiewicz M 1968 O niektórych problematykach z fliszu Karpat Polskich. III. (On some problematic organic traces from the flysch of the Polish Carparthians); Rocz. Pol. Tow. Geol. 38(1) 3-17.

Książkiewicz M 1970 Observations on the ichnofauna of the Polish Caparthians; In: Trace Fossils (eds) Crimes T P and Harper J C, Liverpool, pp. 283-322.

Książkiewicz M 1977 Trace fossils in the flysch of the Polish Carpathians; Palaeontologia Polonica 36 1-208.

Kulkarni K G and Borkar V D 2014 Ichnofauna from the Harbans Bed of the Badhaura Formation (Sterlitmakian), Rajasthan, India; J. Earth Syst. Sci. 123(2) 421-432.

Kumar S and Pandey S K 2008 Discovery of trilobite trace fossils from the Nagaur Sandstone, the Marwar Supergroup, Dulmera area, Bikaner District, Rajasthan; Curr. Sci. 94 1081-1085.

Leszczyński S 1993 A generalised model for the development of ichnocoenoses in flysch deposits; Ichnos 2 137-146.

Leszczyński S 2004 Bioturbation structures of Kropivnick Fucoid Marls (Campanian-Lower Maastrichtian) of Huwniki-Rybotycze area (Polish Carpathians); Geol. Quart. 4891 35-60.

Leymerie M A 1842 Suite de mémoire sur le terrain Crétacé du département de l'Aube; Mémoires de la Société Géologique de France 5 1-34.

Lundgren S A B 1891 Studier öfver fossilförande lösa block; Geol. Fören. Stockholm Förhandl 13 111-121.

MacEachern J A and Pemberton S G 1992 Ichnological aspects of Cretaceous shoreface successions and shoreface variability in the western interior seaway of North America; In: Applications of Ichnology to Petroleum Exploration: A Core Workshop (ed.) Pemberton S G, SEPM, Core Workshop 17 57-84.

Mairenbam C S and Kushwaha R A S 2008 Ichnofossils from the Eocene-Oligocene deposits between Bijang and Tupul, Manipur, India; J. Indian Assoc. Sedimentol. 27 $35-44$.

Mairenbam C S, Kundal P and Kushwaha R A S 2010 Ichnology of Bhuban and Boka Bil Formations, OligoceneMiocene deposits of Manipur Western Hill, northeast India; J. Geol. Soc. India $\mathbf{7 6} 573-586$.

Malarkodi N, Patel S J, Fayazudeen P J and Mallikarjuna U B 2009 Palaeoenvironmental significance of trace fossils from the Palaeocene sediments of Pondicherry area, south India; J. Geol. Soc. India 74 738-748.

Mángano M G, Carmoda N B, Buatois L A and Muniz Guina F 2005 A new ichnospecies of Arthrophycus from 
the Upper Cambrian-Lower Tremadocian of northwest Argentina: Implications for the Arthrophycus lineage and potential in ichnostratigraphy; Ichnos 12 179-190.

Massalongo A 1855 Zoophycos, novum genus plantarum fossilium; Stud. Palaeont. 5 1-43.

Mathur L P and Evans P 1964 Oil in India; 22nd International Congress Proc. Comptes Redus Brochure, pp. 1-87.

Martinsson A 1970 Toponomy of trace fossils; In: Trace fossils (eds) Crimes T P and Harper J C, Geol. J. Spec. Issue 3 323-330.

McCann T 1989 The ichnogenus Desmograpton from the Silurian of Wales: First record from the Paleoxoic; J. Paleontol. 63 950-953.

McCann T 1993 A Nereites ichnofacies from the OrdovicianSilurian Welsh basin; Ichnos 3 39-56.

McIlroy D (ed.) 2004 The application of ichnology to palaeoenvironmental and stratigraphic analysis; Geol. Soc. London Spec. Publ. 228490.

Meneghini G G A 1850 Paleodictyon; In: Observazione stratigrafiche e paleontologiche concernati la geologie dellaToscana e dei paesi limitrofi(Appendix to R R Murchison, MemoriasullastrutturageologiedelleAlpi) (eds) Savi P and Meneghini G, Stamperiagranducale, Firenze, pp. 246528.

Mikuláš R, Lehotský T and Bábek O 2004 Trace fossils of the Moravice Formation from the southern Nízký Jeseník Mts. (Lower Carboniferous, Culm facies; Moravia, Czech Republic); Bull. Geosci. 79 81-98.

Miller W (ed.) 2007 Trace Fossils: Concepts, Problems, Prospects; Elsevier, Amsterdam.

Miller S A and Dyer C B 1878 Contribution to Paleontology, No. 1; J. Cincinnati Soc. Natural History 1 24-39.

Monaco P and Cecconi A 2010 Taphonomy of the graphoglyptid trace fossil Desmograpton Fuchs 1895 at the sole of Miocene thin bedded turbidites, Northern Apennines; Bollettino della Societa Paleontologica Italiana 49 163-172.

Muñiz F and Mayoral A 2001 El icnogénero Spongeliomorpha en el Neógeno superior de la Cuenca del Guadalquivir (Área de Lepe-Ayamonte, Huelva, España); Revista Española de Paleontología 16 115-130.

Myrow P M 1995 Thalassinoides and the enigma of Early Paleozoic open-framework burrow systems; Palaios 10 58-74.

Nagendra R, Patel S J, Deepankar R and Reddy A N 2010 Bathymetric significance of ichnofossil assemblages of the Kulakkalnattam sandstone, Ariyalur area, Cauvery Basin; J. Geol. Soc. India 76 525-532.

Pandey D K, Uchman A, Kumar V and Shekhawat R S 2014 Cambrian trace fossils of the Cruziana ichnofacies from the Bikaner-Nagaur Basin, northwestern Indian Craton; J. Asian Earth Sci. 81 129-141.

Patel S J 2014 Ichnology of shallow marine argillaceous limestone, Miocene, Western Kachchh, India; Palaeontol. Soc. India Spec. Publ. (ISBN: 978-81-926033-2-2), pp. 227-246.

Patel S J and Desai B G 2001 The Republic Day Kachchh Earthquake of 2001: Trauma in Oratosquilla striata; J. Geol. Soc. India 58 215-216.

Patel S J, Desai B G, Vaidya A D and Shukla R 2008 Middle Jurassic trace fossils from Habo Dome, mainland Kachchh, western India; J. Geol. Soc. India 71 345-362.

Patel S J, Desai B G and Shukla R 2009 Paleoecological significance of the trace fossils of Dhosa Oolite Member (Jumara Formation), Jhura Dome, mainland Kachchh, western India; J. Geol. Soc. India 74 601-614.

Patel S J, Joseph J K and Bhatt N Y 2014 Ichnology of the Goradongar Formation, Goradongar Hill Range, Patcham Island, Kachchh, western India; J. Geol. Soc. India 84 $129-154$.
Pemberton S G and Frey R W 1982 Trace fossil nomenclature and the Planolites-Palaeophycus dilemma; J. Paleontol. 56 843-871.

Pemberton S G, Spila M, Pulham A J, Saunders T, MacEachern J A, Robbins D and Sinclair I K 2001 Ichnology and sedimentology of shallow to marginal marine systems; Geol. Assoc. Canada, Ontario, Short course notes 15.

Pervesler P and Uchman A 2004 Ichnofossils from the type area of the Grund Formation (Miocene, Lower Badenian) in northern Lower Austria (Molásse Basin); Geologica Carpathica 55 103-110.

Pickerill R K 1981 Trace fossils in a Lower Paleozoic submarine canyon sequence - the Siegas Formation of northwestern New Brunswick, Canada; Maritime Sed. Atlantic Geol. 17 36-59.

Rajkonwar C, Tiwari R P and Patel S J 2013 Arenicolites helixus isp. nov. and associated ichnospecies from the Bhuban Formation, Surma Group (Lower-Middle Miocene) of Aizawl, Mizoram, India; Him. Geol. 34 18-37.

Rajkonwar C, Ralte V Z, Lianthangpuii P C, Tiwari R P and Patel S J 2014a Miocene ichnofossils from Upper Bhuban succession, Bhuban Formation (Surma group), Mizoram, India; Paleontol. Soc. India Spec. Publ. (ISBN: 978-81926033-2-2), pp. 247-255.

Rajkonwar C, Ralte V Z, Lianthangpuii P C, Tiwari R P and Patel S J 2014b Additional ichnofossil from Middle Bhuban Unit, Bhuban Formation, Surma Group (Lower to Middle Miocene), Mizoram and their environmental significance; Paleontol. Soc. India Spec. Publ. (ISBN: 978-81-926033-2-2), pp. 257-271.

Rajkumar H S 2005 Significance of trace fossils from DisangBarail Transition Zones, Imphal Valley; Him. Geol. 26 323-326.

Rajkumar H S and Klein H 2014 First perissodactyl footprints from flysch deposits of the Barail Group (Lower Oligocene) of Manipur, India; J. Earth Syst. Sci. 123(2) 413-420.

Rajkumar H S, Rodríguez-Tovar F J and Soibam I 2008 Trace fossils of the Upper Eocene-Lower Oligocene transition of the Manipur, Indo-Myanmar Ranges (northeast India); Turkish J. Earth Sci. 17 821-834.

Rajkumar H S, Khaidem K S, Soibam I and Sanasam S S 2012 Palaeoenvironment of the Middle Bhuban, Surma Group, Mizoram, India: An ichnological approach; J. Indian Assoc. Sedimentol. 31(1\&2) 65-79.

Rao R A 1983 Geology and hydrocarbon potential of a part of Assam-Arakan basin and its adjacent region; Petroleum Asia J. 1 127-158.

Rindsberg A K 1994 Ichnology of the Upper Mississippian Hartselle Sandstone of Alabama, with notes on other Carboniferous formations; Bull. Geol. Surv. Alabama L58 $1-107$.

Rodríguez-Tovar F J 2010 Ichnological analysis and sequence stratigraphy research: Present-day and prospective; Geol. Soc. India Memoir 75 99-114.

Rodríguez-Tovar F J, Perez-Valera F and Perez-Lopez A 2007 Ichnological analysis in high-resolution sequence stratigraphy: The Glossifungites ichnofacies in Triassic successions from the Betic Cordillera (southern Spain); Sedim. Geol. 198 293-307.

Roniewicz P and Pienkowski G 1977 Trace fossils of the Podhale Flysch Basin; In: Trace fossils 2 (eds) Crimes T P and Harper J C, Geol. J. Spec. Issue 12 273-288.

Sacco F 1888 Note di Paleoicnologia Italiana; Atti Soc. Ital. Sc. Nat. 31 151-192.

Saha O, Shukla U K and Rani R 2010 Trace fossils from the Late Cretaceous Lameta Formation, Jabalpur area, Madhya Pradesh: Palaeoenvironmental implications; J. Geol. Soc. India 76 607-620. 
Saporta Gaston De 1887 Nouveaux documents relatifs aux organismes problématiques des anciennes mers; Société Géologique de France, Bulletin 3 286-302.

Savi P and Meneghini G G 1850 Osservazioni stratigrafiche e paleontologischeconcernati la geologia della Toscana e dei paesi limitrofi. Appendix. In: Memoria sulla struttura geologica delle Alpi, degli Apennini e dei Carpazi (ed.) Murchison R I, Stamperia granducale, Firenze, pp. 246-528.

Savrda C H, Krawinkel H, McCarthy F M G, McHugh C M G, Olson H C and Mountain G 2001 Ichnofabrics of a Pleistocene slope succession, New Jersey margin: Relations to climate and sea-level dynamics; Palaeogeogr. Palaeoclimatol. Palaeoecol. 171 41-46.

Schäfer W 1972 Ecology and Paleontology of Marine Environments, Edinburgh, pp. 1-568.

Schlirf M and Uchman A 2005 Revision of the ichnogenus Sabellarifex Richter, 1921 and its relationship to Skolithos Haldeman, 1840 and Polykladichnus Fürsich, 1981; J. Syst. Palaeontol. 3 115-131.

Seilacher A 1955 Spuren und Fazies im Unterkambrium; In: Beiträge zur Kenntnis des Kambrium in der Salt Range (Pakistan) (eds) Schinderwolf O H and Seilacher A, Akademic der Wissenschaften und der Literatur zu Mains, mathematischnaturwissen-schaftliche Klasse, Abhandlungen 10 373-399.

Seilacher A 1962 Palaeontological studies on turbidite sedimentation and erosion; J. Geol. 70 277-234.

Seilacher A 1964 Biogenic sedimentary structures; In: Approaches to Palaeontology (eds) Wiley and Sons, New York, pp. 296-316.

Seilacher A 1967 Bathymetry of trace fossils; Marine Geol. 5 413-428.

Seilacher A 1977a Pattern analysis of Paleodictyon and related trace fossils; In: Trace fossils 2 (eds) Crimes T P and Harper J C, Geol. J. Spec. Issue 9 289-334.

Seilacher A 1977b Evolution of trace fossil communities; In: Patterns of evolution (ed.) Hallam A, Elsevier, Amsterdam, pp. 359-376.

Seilacher A 2007 Trace Fossil Analysis; Springer, Berlin, 226p.

Seilacher A and Seilacher E 1994 Bivalvian trace fossils: A lesson from actuopaleontology; Courier Forschungsinstitut Senckenberg 169 5-15.

Simpson S 1957 On the trace fossil Chondrites; Quart. J. Geol. Soc. 112 475-500.

Soibam I 1998 On the geology of Manipur; In: Souvenir, IX Manipur Science Congress (March 25-27), pp. 12-19.

Soibam I 2000 Structural and tectonic framework of Manipur; In: Souvenir, X Manipur Science Congress (March 15-17), pp. 26-37.

Soibam I, Sanasam S S, Khuman Ch M and Rajkumar H S 2013 Indo-Myanmar ranges: Sedimentary basin of continental margin; In: Souvenir, National Conference on Sedimentation and Tectonics with Special Reference to Energy Resources of Northeast India and XXX Convention of Indian Association of Sedimentologists (November 28-30, 2013), pp. 61-81.

Srivastava A K and Mankar R S 2012 Trace fossils and their palaeoenvironmental significance in the Lameta Formation of Salbardi and Belkher area, district Amravati, Maharashtra, India; Arabian J. Geosci. 5(5) 1003-1009.

Tchoumatchenco P and Uchman A 2001 The oldest deep-sea Ophiomorpha and Scolicia and associated trace fossils from the Up. Jurassic-Lr. Cretaceous deep-water turbidite deposits of SW Bulgaria; Palaeogeogr. Palaeoclimatol. Palaeoecol. 169 85-99.

Tewari A, Hart M B and Watkinson M P 1998 Teredolites from the Garudamangalam Sandstone Formation (late Turonian-Coniacian), Cauvery Basin, southeast India; Ichnos 6 75-98.
Tiwari R P, Rajkonwar C, Lalchawimawii, Malsawma P L J, Ralte V Z and Patel S J 2011 Trace fossils from Bhuban Formation, Surma Group (Lower to Middle Miocene) of Mizoram India and their palaeoenvironmental significance; J. Earth Syst. Sci. 120(6) 1127-1143.

Tiwari R P, Rajkonwar C and Patel S J 2013 Funalichnus bhubani isp. nov. from Bhuban Formation, Surma Group (Lower-Middle Miocene) of Aizawl, Mizoram, India; PLoS ONE 8(10) e77839, doi: 10.1371/journal.pone.0077839.

Torell O M 1870 Petrifacta Suecana Formationis Cambricae; Lunds Universitet, Arsskrift; Lund 6(2/8) 1-14.

Tripathi C and Satsangi P P 1982 Crustacean burrows from the Disang Group of Manipur; Indian Minerals 36 $24-26$.

Uchman A 1995 Taxonomy and paleoecology of flysch trace fossils: The Marnoso Arenacea Formation and associated facies (Northern Appenines, Italy); Beringeria 15 $3-115$.

Uchman A 1998 Taxonomy and ethology of flysch trace fossils: A revision of the Marian Ksiäżkiewicz collection and studies of complimentary materials; Annales Societatis Geologorum Poloniae 68 105-218.

Uchman A 1999 Ichnology of the Rhenodanubian Flysh (Lower Cretaceous-Eocene) in Austria and Germany; Beringeria 25 67-173.

Uchman A and Demircan H 1999 Trace fossils of Miocene deep sea fan fringe deposits from the Cingoz Formation, southern Turkey; Annales Societatis Geologorum Poloniae 69 125-135.

Uchman A and Gaździcki A 2006 New trace fossils from the La Meseta Formation (Eocene) of Seymour Island, Antarctica; Polish Polar Res. 27 153-170.

Uchman A and Wetzel A 2011 Deep-sea ichnology: The relationships between depositional environment and endobenthic organisms (eds) Hüneke $\mathrm{H}$ and Mulder H, Dev. Sedim., Amsterdam: The Netherlands 63 517-556.

Uchman A, Bubniak I and Bubniak A 2000 The Glossifungites ichnofacies in the area of its nomenclatural archetype, Lviv, Ukraine; Ichnos 7 183-193.

Uchman A, Janbu N E and Nemec W 2004 Trace fossils in the Cretaceous-Eocene flysch of the Sinop-Boyabat Basin, central Pontides, Turkey; Annales Societatis Geologorum Poloniae 74 197-235.

Uchman A, Hanken N M and Binns R 2005 Ordovician bathyal trace fossils from metasiliciclastics in central Norway and their sedimentological and paleogeographical implications; Ichnos 12 105-133.

Uchman A, Kazakaukas V and Gaigalas A 2009 Trace fossils from Late Pleistocene varved lacustrine sediments in eastern Lithuania; Palaeogeogr. Palaeoclimatol. Palaeoecol. 272 199-211.

Vossler S M and Pemberton S G 1989 Ichnology and paleoecology of offshore siliciclastic deposits in the Cardium Formation (Turonian, Alberta, Canada); Palaeogeogr. Palaeoclimatol. Palaeoecol. 74 217-239.

Vyalov O S 1971 Rare Mesozoic problematica from the Pamir and Caucasus; Paleont. Sbornik, Izdatel. Lvov. Univ., Vyp. Vtroroy no. 7 85-93.

Weller S 1899 Kinderbook faunal studies I. The fauna of the vermicular sandstone at Northview, Webster County, Missouri; Acad. Sci. St. Louis, Trans. 9 2-6.

Wetzel A 1991 Ecologic interpretation of deep-sea trace fossil communities; Palaeogeogr. Palaeoclimatol. Palaeoecol. 85 47-69.

Wetzel A 2010 Deep-sea ichnology: Observations in modern sediments to interpret fossil counterparts; Acta Geologica Polonica 60(1) 125-138.

Woodward S 1830 A synoptic table of British Organic remains; London \& Norwich, 50p. 
Worsley D and Mørk A 2001 The environmental significance of the trace fossil Rhizocorallium jenense in the Lower Triassic of western Spitsbergen; Polar Res. 20 37-48.

Yengkhom R S, Sijagurumayum U and Rajkumari R D 2010 Preliminary studies of fossils from the Paleogene rocks exposed around Changamdabi area, Manipur; Geol. Soc. India Memoir 75 143-148.

Yengkhom R S, Li J, Singh B P and Guruaribam V 2013 Microforaminiferal linings from the upper part of the Upper Disang Formation at Gelmoul quarry,
Churachandpur, Imphal Valley and their bearing on palaeoenvironment; Curr. Sci. 105(9) 1223-1226.

Yochelson E L and Fedonkin M A 1997 The type specimens (middle Cambrian) of the trace fossil Archaeonassa Fenton and Fenton; Canadian J. Earth Sci. 34 12101219.

Zenker J C (ed.) 1836 Historisch-topographisches Taschenbuch von Jena und seiner Umgebung besonders in naturwissenschaftlicher und medicinischer Beziehung $\mathbf{3 3 8}$ Wackenhoder (Jena).

MS received 24 October 2014; revised 2 March 2015; accepted 10 March 2015 